\title{
Unraveling Evolutionary Relationships Among the Divergent Lineages of Colletotrichum Causing Anthracnose Disease in Turfgrass and Corn
}

\author{
Jo Anne Crouch, Bruce B. Clarke, and Bradley I. Hillman
}

Department of Plant Biology and Pathology, Rutgers University, 59 Dudley Road, New Brunswick, NJ 08901. Accepted for publication 30 August 2005.

\begin{abstract}
Crouch, J. A., Clarke, B. B., and Hillman, B. I. 2006. Unraveling evolutionary relationships among the divergent lineages of Colletotrichum causing anthracnose disease in turfgrass and corn. Phytopathology 96: 46-60.

Colletotrichum species cause anthracnose diseases on a number of grass hosts and are common inhabitants of many others. They are divided into four species: C. sublineolum is pathogenic to Sorghum spp.; C. caudatum is found on $\mathrm{C} 4$ grasses such as indiangrass and big bluestem; $C$. falcatum causes red rot of sugarcane; and $C$. graminicola sensu lato is a broadly defined species including isolates that attack maize, wheat, oats, and many forage, turf, and amenity grasses of the subfamily Pooideae. In this paper, a combination of hierarchal- and nonhierarchal-

based analyses were employed to examine evolutionary relationships among the grass-infecting Colletotrichum species, with special emphasis on isolates from turf and other grasses in the subfamily Pooideae. Reconstructions performed with data sets from over 100 Colletotrichum isolates at three variable loci using phylogenetic and network-based methodologies unambiguously supported the taxonomic separation of maizeinfecting isolates of $C$. graminicola from the pooid-infecting strains of Colletotrichum. To reflect the evolutionary relationships that exist between these distinct lineages, we propose the resurrection of the species name $C$. cereale to describe the pooid-infecting isolates. There was also support for further subdivision of $C$. cereale, but the current data are insufficient to confidently subdivide the species, as there was some evidence of recombination between lineages of this species.
\end{abstract}

When confronted with fungi that rapidly emerge as destructive pathogens in cultivated plant communities, an understanding of how genetic variation is organized often allows us to reconstruct the sequence of events influencing both the onset and trajectory of disease epidemics. By considering fungal phytopathogen life histories and diversity, it has been possible to deduce the events that have shaped many of the most destructive plant disease outbreaks during the past century. For example, the manifestation of the Dutch elm disease pandemics caused by Ophiostoma spp. is known to be characterized by a series of rapid intercontinental migratory events, introgressive gene transfers resulting in novel hybrid genotypes, and, significantly, by the replacement of one pathogen $(O$. ulmi) by a new, more destructive species $(O$. novoulmi) (11 for review). Similarly, by reconstructing phylogenetic relationships among host-specific populations of the rice blast pathogen (Magnaporthe oryzae), a recent study suggests that host shifts of the pathogen from non-rice plants to rice crops occurred during the era of rice domestication (17). Pursuit of this knowledge is not merely academic: with enough information, plant pathologists have a greater probability of implementing successful disease control measures.

In cereals and grasses, anthracnose disease is caused by four distinct Colletotrichum species, each delimited partly by host

Corresponding author: B. I. Hillman; E-mail address: hillman@ aesop.rutgers.edu All sequences have been deposited in GenBank (accession nos. DQ126157 to DQ126262, DQ131924 to DQ132027, DQ132028 to DQ132051, and DQ133257 to DQ133340).

* The $\boldsymbol{e}$-Xtra logo stands for "electronic extra" and indicates that the online version contains supplemental material not included in the print edition. The online version contains maximum parsimony trees of ITS, HMG box, and SOD2 regions, and a representative sample of the sequence alignments that were the basis for those trees.

DOI: 10.1094/PHYTO-96-0046

(C) 2006 The American Phytopathological Society specificity, but primarily differentiated by morphological features. C. sublineolum Henn. is pathogenic to Sorghum spp.; C. caudatum Peck is found on a number of $\mathrm{C} 4$ grasses such as indiangrass and big bluestem (Sorghastrum nutans (L.) Nash and Andropogon gerardii Vitman, respectively); and C. falcatum Went causes red rot of sugarcane (Saccharum officinarum L.). C. graminicola (Ces.) G.W. Wilson is generally considered to inhabit a wide range of hosts including corn (Zea mays L.), wheat (Triticum aestivum L.), oats (Avena sativa L.), and many forage, turf, and amenity grasses of the Poaceae subfamily Pooideae (71). Sutton formally proposed in 1980, however, that the species circumscription is properly applied only to Colletotrichum on corn; therefore, valid publication of $C$. graminicola sensu stricto Sutton rendered illegitimate the application of the name $C$. graminicola to any Colletotrichum from hosts other than corn (61). As no diagnoses of a new species taxon for the fungi distributed on pooid grasses has been established, C. graminicola sensu lato G.W. Wilson is still routinely, but inappropriately, employed to describe these strains (10).

Historically, C. graminicola sensu lato G.W. Wilson was known as a plant pathogen of minor importance $(18,20)$, and in almost all grasses this is still true. But toward the end of the 20th century, two devastating anthracnose disease epidemics caused by $C$. graminicola occurred quite suddenly in North America: first, in corn crops and later in turfgrasses of the subfamily Pooideae cultivated as golf course greens (especially annual bluegrass [Pоа апnиа L.] and creeping bentgrass [Agrostis stolonifera L.]). The recent disease upsurge caused by $C$. graminicola has devastated turfgrasses maintained as golf course greens since the early 1990s and shows no signs of abating. In turf, changing cultivation practices are likely a contributing factor to disease development, as stands of grass are exposed to increasingly harsh management regimes designed to enhance playability for golfers. Factors such as minimal nitrogen fertilization, decreased cutting heights, variability in fungicide efficacy, and the increased usage of plant growth regulating chemicals have all been implicated in the enhancement of 
anthracnose disease levels (22; J. Inguagiato and B. B. Clarke, unpublished data).

As anthracnose disease in turfgrasses attributed to $C$. graminicola became increasingly problematic throughout the 1990s, a number of research groups conducted analyses of molecular genetic diversity or inferred gene genealogies intended to characterize variability in the $C$. graminicola species group. Several conflicting hypotheses were proposed concerning the evolution and diversity of $C$. graminicola, but no theory has generally been accepted as an accurate representation of the species history. Molecular data were used to suggest a close connection between $C$. sublineolum and isolates of Colletotrichum causing anthracnose in annual bluegrass turf $(6,30)$, whereas another study supported an association between isolates from creeping bentgrass turf and those from corn (6). Results from other research groups supported a separate lineage of turfgrass pathogens, diverged from corn and sorghum isolates, which share a single ancestor $(12,19,25,31)$.

In this study, we jointly consider three complementary data sets to investigate the patterns of evolutionary relationships among Colletotrichum isolates responsible for anthracnose disease in turfgrasses, corn, and other grass hosts. We tested the following expectations: (i) C. graminicola sensu lato G.W. Wilson is actually an assemblage of divergent lineages, rather than a single cohesive species; and (ii) although this fungus appears to reproduce clonally through asexual conidia (16), with the sexual state (Glomerella) not yet observed in a natural setting, lineages of these fungi may still be structured to some degree by reticulate evolution. To consider these concepts, data from over $100 \mathrm{Col}$ letotrichum isolates from grasses and cereals were collected from more than 88 populations throughout the United States and Canada. A combination of hierarchal- and nonhierarchal-based approaches that were used to test the limits of species boundaries rigorously provides compelling evidence of sympatric, specieslevel phylogenetic divergence between $C$. graminicola pathogenic to maize and Colletotrichum populations causing disease in grasses of the subfamily Pooideae, including cultivated C3 turfgrass species. In particular, these analyses demonstrated that $\mathrm{Col}$ letotrichum spp. isolated from maize and pooid grasses are each more closely related to $C$. sublineolum from sorghum than these two lineages are to one another. To reflect the evolutionary relationships that exist between these distinct organisms, we formally propose to resurrect and revise the species C. cereale Manns (54) to describe the unique lineages isolated from pooid grasses, while C. graminicola sensu stricto Sutton uniquely describes Colletotrichum from corn hosts. To aid communication throughout this narrative and to emphasize the fundamental distinction to be made between these highly divergent lineages, we will henceforth refer to any Colletotrichum specimen isolated from pooid grasses as a member of the $C$. cereale species group, and C. graminicola as the species of Colletotrichum pathogenic to corn.

\section{MATERIALS AND METHODS}

Taxon sampling for molecular analysis. A total of 107 specimens of $C$. graminicola isolated from North American grasses (Table 1) were assessed for this study, with the majority of individuals $(76 \%)$ isolated from diseased stands of turfgrass maintained as golf course greens. This sample collection includes specimens from 88 localities, and closely reflects the geographic regions where anthracnose disease on golf course greens has been most prevalent in North America; not all known localities were sampled.

Collected fungi were established in pure culture on potato dextrose agar (PDA; Fisher Scientific, Hampton, NH) and then singlespore purified to ensure isogenic lines. Cultures were preserved as dehydrated mycelia on Whatman glass fiber at $-20^{\circ} \mathrm{C}$. Identification of fungal colonies as Colletotrichum was performed using spore and setae morphological characters and later confirmed by performing a BLAST search (3) of the partial ribosomal DNA (rDNA) sequences against the National Center for Biotechnology Information (NCBI) database.

Outgroup taxa. Phylogenetic relationships within the genus Colletotrichum are currently ill-defined, making the choice of an appropriate outgroup to root our phylogenetic tree uncertain based upon previously published hypotheses. Traditional Colletotrichum systematics relies heavily upon host plant association (13); this criterion has been repeatedly shown to be unreliable for the genus; in some instances several species are capable of infecting a single host plant $(37,42)$ or a single species may be associated with an extremely broad host range ( 28 for review). Morphological characters in the genus may also be systematically uninformative, and are often inadequate to resolve even interspecific relationships with any level of confidence (62). Likewise, molecular investigations of the group conducted to date fail to infer evolutionary relationships between the Colletotrichum taxa robustly. Instead, unresolved, minimally supported topologies from which no significant conclusions can be drawn have been found (45). Because of the ambiguous state of Colletotrichum taxonomy, we constructed a phylogenetic tree using the nucleotide sequence from the rDNA internal transcribed spacer (ITS) region to select an appropriate species empirically as outgroup taxa for this study. BLAST searches of the NCBI database GenBank using the ITS sequence from strains MO-1001178, PA-50005, and NJ-6340 identified a number of Colletotrichum species likely to be closely related to $C$. graminicola. Twenty-four sequences were analyzed (AY536046, AF272786, AF489567, AJ301951, AJ301922, AF272783, AF272782, AB042305, AB042304, AY376530, AB196301, AJ301954, AF411770, AJ536231, AF534469, AJ301975, AJ301968, and AJ311391) along with a representative selection of $C$. graminicola ingroup taxa. Based upon the resultant $75 \%$ consensus tree topology (data not shown), four isolates of $C$. sublineolum from sorghum were included in this study, since this species appeared to be a closely related sister taxon to $C$. graminicola. In addition, two isolates of $C$. acutatum J.H. Simmonds were included as outgroup taxa because they are clearly distinct from $C$. graminicola both morphologically and on the molecular level, yet still show a close enough relationship to allow for unambiguous nucleotide sequence alignments.

DNA isolation, amplification and sequencing. Total genomic DNA was extracted from fungal cultures using a standard phenol/ chloroform protocol as described (19). Polymerase chain reaction (PCR) products for the ITS region of the ITS1, 5.8S, and ITS2 rDNA and the conserved HMG-box of the MAT1-2 mating-type locus (HMG) were generated using published primer pairs and amplification conditions: ITS4 and ITS5 (70) for the ITS region, NcHMG 1 and 2 (4) or CgHMG 1 and 2 (66) for the HMG sequence. New primer pairs were designed to amplify a 625 - or 505-bp portion of a single copy manganese-type superoxide dismutase gene (SOD2) (26): SOD625F/R (5'GCCCACAGTACATATTGCCTAAGC3' and 5'TCATCCCGGGAGCCAGAAAACCT3') or SOD507F/R (5'ATGGCAGCCTTTCCGTTGAGATAC$3^{\prime}$ and 5'AGTTGACATGAAGCCACCTACAGC3'). PCR primers were synthesized by Sigma Genosys (The Woodlands, TX), and all amplifications were performed in a Biometra UNO thermoblock (Whatman Biometra, Goettingen, Germany) in 25- $\mu$ l reactions using $37.5 \mathrm{ng}$ of genomic DNA, 1 unit of Taq DNA polymerase (Promega, Madison, WI) in $10 \times$ PCR buffer, $1.5 \mathrm{mM}$ $\mathrm{MgCl}_{2}, 0.2 \mathrm{mM}$ of each dNTP, and $12.5 \mathrm{ng}$ of each primer. SOD2 products were amplified from genomic DNA using an initial denaturation at $95^{\circ} \mathrm{C}$ for $5 \mathrm{~min}$ followed by 40 cycles of denaturation at $95^{\circ} \mathrm{C}$ for $1 \mathrm{~min}$, annealing at $53^{\circ} \mathrm{C}$ for $1 \mathrm{~min}$, and extension at $72^{\circ} \mathrm{C}$ for $1 \mathrm{~min}$; with a final extension at $72^{\circ} \mathrm{C}$ for $10 \mathrm{~min}$. Negative controls were included in all amplifications to check for possible contamination. Amplified fragments were visualized on $0.8 \%$ agarose gels, and then excised and purified using the Gene Clean III Kit (Qbiogene, Irvine, CA). Nucleotide sequences were 
generated from the forward and reverse strands directly from the amplicon using the corresponding PCR primers and BigDye Terminator cycle-sequencing chemistry (Applied Biosystems, Foster City, CA) on an ABI 3100 Capillary Sequencer following the manufacturer's protocol but using a quarter of the suggested reaction volume.

Nucleotide sequences were assembled and edited using the Lasergene Sequence Analysis Software package (DNASTAR, Inc., Madison, WI). Three hundred eighteen DNA sequences were deposited in GenBank under accession nos. DQ126157 to DQ126262 (ITS), DQ131924 to DQ132027 (HMG), and DQ132028 to
DQ132051 and DQ133257 to DQ133340 (SOD2). The remaining 15 sequences were not reported because they overlapped data already placed by $\mathrm{Du}$ et al. (25) (DQ003109-12, DQ003114, DQ003116-17, DQ002855-59, DQ002826, DQ002862, DQ002865, and DQ002868). Sequences were aligned using the Clustal W algorithm (65) and then manually adjusted in Microsoft Word (Microsoft Corp., Redmond, WA). The alignment of protein coding regions was refined according to amino acid sequences and intron positions. Gaps were removed from the data set, coded as single multi-state characters, and then reintroduced as coded data for the phylogenetic analyses.

TABLE 1. Sources of Colletotrichum isolates used in this study

\begin{tabular}{|c|c|c|c|c|c|c|}
\hline Clade $^{\mathrm{a}}$ & $\begin{array}{l}\text { Haplotype } \\
\text { (frequency) }\end{array}$ & Isolate name & Host species & Origin & Source & $\begin{array}{l}\text { Original } \\
\text { reference }\end{array}$ \\
\hline$\cdots$ & $1(1)$ & $\begin{array}{l}\text { NJ-CACA } \\
\text { (outgroup) }\end{array}$ & $\begin{array}{l}\text { Calamagrostis acutifolia } \\
\text { (C. acutatum) }\end{array}$ & New Jersey & $\cdots$ & This study \\
\hline B & $2(1)$ & ALB-99325 & Poa pratensis & Alberta, Canada & T. Hsiang & This study \\
\hline A & $3(1)$ & MA-6722 & Роа аппиа & Massachusetts & $\ldots$ & This study \\
\hline A & $4(1)$ & CT-6956 & Роа аппиа & Connecticut & $\ldots$ & This study \\
\hline A & $5(22)$ & CA-62 & Pоа аппиа & California & F. Wong & This study \\
\hline A & $5(22)$ & CA-1049 & Pоа аппиа & California & F. Wong & This study \\
\hline A & $5(22)$ & CA-1143 & Pоа аппиа & California & F. Wong & This study \\
\hline A & $5(22)$ & CA-CL9 & Роа аппиа & California & F. Wong & This study \\
\hline A & $5(22)$ & CA-SH29 & Роа аппиа & California & F. Wong & This study \\
\hline A & $5(22)$ & CT-2 & Роа аппиа & Connecticut & N. Jackson & (12) \\
\hline A & $5(22)$ & IL-P6G & Роа аппиа & Illinois & N. Jackson & (12) \\
\hline A & $5(22)$ & IL-PT & Poа аппиа & Illinois & R. Kane & This study \\
\hline A & $5(22)$ & IL-PV1 & Роа аппиа & Illinois & R. Kane & This study \\
\hline A & $5(22)$ & IL-PV2 & Pоа аппиа & Illinois & R. Kane & This study \\
\hline A & $5(22)$ & IL-RCC & Роа аппиа & Illinois & R. Kane & This study \\
\hline A & $5(22)$ & NJ-6795 & Роа аппиа & New Jersey & $\ldots$ & This study \\
\hline A & $5(22)$ & NJ-7284 & Роа аппиа & New Jersey & $\ldots$ & This study \\
\hline A & $5(22)$ & NY-8422 & Роа аппиа & New York & $\ldots$ & This study \\
\hline A & $5(22)$ & NY-USGA & Роа аппиа & New York & $\ldots$ & This study \\
\hline A & $5(22)$ & ONT-00176 & Agrostis stolonifera & Ontario, Canada & T. Hsiang & This study \\
\hline A & $5(22)$ & PA-50014 & Роа аппиа & Pennsylvania & W. Uddin & This study \\
\hline A & $5(22)$ & PA-50111 & Роа аппиа & Pennsylvania & W. Uddin & This study \\
\hline A & $5(22)$ & PA-50231 & Роа аппиа & Pennsylvania & W. Uddin & This study \\
\hline A & $5(22)$ & PA-V1 & Роа аппиа & Pennsylvania & W. Uddin & This study \\
\hline A & $5(22)$ & PA-WH3 & Роа аппиа & Pennsylvania & W. Uddin & This study \\
\hline A & $5(22)$ & RI-8 & Pоа аппиа & Rhode Island & N. Jackson & (12) \\
\hline A & $6(1)$ & NBR-13 & Роа аппиа & New Brunswick, Canada & N. Jackson & (12) \\
\hline A & $7(1)$ & CA-540 & Роа аппиа & California & F. Wong & This study \\
\hline A & $8(1)$ & CO-8910 & Роа аппиа & Colorado & $\ldots$ & This study \\
\hline A & $9(4)$ & KS-20DGU & Dactylis glomerata & Kansas & $\ldots$ & This study \\
\hline A & $9(4)$ & KS-20DGY & Dactylis glomerata & Kansas & $\ldots$ & This study \\
\hline A & $9(4)$ & KS-20EVD & Elymus virginicanus & Kansas & $\ldots$ & This study \\
\hline A & $9(4)$ & KS-20EVM & Elymus virginicanus & Kansas & $\ldots$ & This study \\
\hline A & $10(1)$ & NJ-CA1 & Calamagrostis acutifolia & New Jersey & $\ldots$ & This study \\
\hline A & $11(1)$ & NJ-DG1 & Dactylis glomerata & New Jersey & $\ldots$ & This study \\
\hline A & $12(1)$ & NJ-8627 & Роа аппиа & New Jersey & $\ldots$ & This study \\
\hline A & $13(1)$ & KS-10EC1A & Elymus canadensis & Kansas & $\ldots$ & This study \\
\hline A & $14(1)$ & NY-8900 & Роа аппиа & New York & $\ldots$ & This study \\
\hline A & $15(1)$ & NJ-8626 & Роа аппиа & New Jersey & $\ldots$ & This study \\
\hline A & $16(1)$ & NJ-6340 & Роа аппиа & New Jersey & $\ldots$ & This study \\
\hline A & $17(2)$ & CA-EG15 & Pоа аппиа & California & F. Wong & This study \\
\hline A & $17(2)$ & CA-SC44 & Роа аппиа & California & F. Wong & This study \\
\hline A & $18(1)$ & MA-11 & Pоа аппиа & Massachusetts & N. Jackson & (12) \\
\hline A & $19(1)$ & CT-14 & Роа аппиа & Connecticut & N. Jackson & (12) \\
\hline A & $20(1)$ & KS-20BIG & Bromus inermis & Kansas & $\ldots$ & This study \\
\hline A & $17(2)$ & NJ-9582 & Роа аппиа & New Jersey & $\ldots$ & This study \\
\hline A & $17(2)$ & PA-50183 & Роа аппиа & Pennsylvania & W. Uddin & This study \\
\hline A & $22(1)$ & CA-SC32 & Роа аппиа & California & F. Wong & This study \\
\hline A & $23(1)$ & CA-1715 & Роа аппиа & California & F. Wong & This study \\
\hline A & $24(1)$ & RI-22 & Agrostis stolonifera & Rhode Island & N. Jackson & (12) \\
\hline B & $25(1)$ & PA-50002 & Роа аппиа & Pennsylvania & W. Uddin & This study \\
\hline B & $26(1)$ & CT-28 & Agrostis stolonifera & Connecticut & N. Jackson & (12) \\
\hline B & $27(1)$ & NJ-6607 & Роа аппиа & New Jersey & $\ldots$ & This study \\
\hline B & $28(1)$ & MA-17 & Agrostis stolonifera & Massachusetts & N. Jackson & (12) \\
\hline B & $29(1)$ & ONT-00133 & Agrostis stolonifera & Ontario, Canada & T. Hsiang & This study \\
\hline B & $30(1)$ & CT-25 & Agrostis stolonifera & Connecticut & N. Jackson & (12) \\
\hline B & $31(3)$ & MA-20 & Agrostis stolonifera & Massachusetts & N. Jackson & (12) \\
\hline \multicolumn{7}{|c|}{ (Continued on next page) } \\
\hline
\end{tabular}

a Clades A to D are inferred from multilocus sequence analyses, as shown in Figure 1. 
Phylogenetic analyses. We used both Bayesian maximum likelihood (ML) and maximum parsimony (MP) methods to infer phylogenetic relationships from each gene region and for the combined data set. Models of evolution and ML parameters were estimated individually for each data set using the Akaike information criterion (AIC) (1) as implemented in Modeltest version 3.06 (47). Bayesian analyses were performed using MrBayes version 3.0b4 (34), which allowed the different data partitions to be modeled separately using the evolutionary models and informative priors that best described the data. The optimal model selected under the AIC implemented in Modeltest was specified as prior for each gene. One cold and three incrementally heated
Metropolis-coupled Monte Carlo Markov chains were started from random trees and run simultaneously for 14,000,000 generations each in order to sample the phylogenies according to their posterior probabilities. Three replicate runs were performed, and tree topologies and stationarity levels were compared for convergence (34). To determine the point at which stationarity was achieved in each run, log likelihood scores were plotted against generation time; the initial generations sampled before convergence were discarded as burn-in. We sampled trees from every 500 generations across all four independent analyses to calculate posterior probabilities for each branch in the ML tree. Trees sampled from the posterior distribution were imported into

TABLE 1. (Continued from preceding page)

\begin{tabular}{|c|c|c|c|c|c|c|}
\hline Clade $^{\mathrm{a}}$ & $\begin{array}{l}\text { Haplotype } \\
\text { (frequency) }\end{array}$ & Isolate name & Host species & Origin & Source & $\begin{array}{l}\text { Original } \\
\text { reference }\end{array}$ \\
\hline B & $31(3)$ & MA-21 & Agrostis stolonifera & Massachusetts & N. Jackson & $(12)$ \\
\hline B & $31(3)$ & ONT-00128 & Agrostis stolonifera & Ontario, Canada & T. Hsiang & This study \\
\hline B & $32(2)$ & ONT-00124 & Agrostis stolonifera & Ontario, Canada & T. Hsiang & (16) \\
\hline B & $32(2)$ & ONT-00126 & Agrostis stolonifera & Ontario, Canada & T. Hsiang & This study \\
\hline B & $33(1)$ & PA-50621 & Poа аппиа & Pennsylvania & W. Uddin & This study \\
\hline B & $34(1)$ & NY-19 & Agrostis stolonifera & New York & N. Jackson & (12) \\
\hline B & $35(1)$ & PA-4410 & Poа аппиа & Pennsylvania & W. Uddin & This study \\
\hline B & $36(1)$ & NJ-6491 & Роа аппиа & New Jersey & $\ldots$ & This study \\
\hline B & $37(2)$ & NJ-4990 & Pоа аппиа & New Jersey & $\ldots$ & This study \\
\hline B & $37(2)$ & PA-1112 & Роа аппиа & Pennsylvania & W. Uddin & This study \\
\hline B & $38(2)$ & PA-50005 & Poа аппиа & Pennsylvania & W. Uddin & This study \\
\hline B & $38(2)$ & PA-50181 & Poа аппиа & Pennsylvania & W. Uddin & This study \\
\hline B & $39(1)$ & MA-24 & Agrostis stolonifera & Massachusetts & N. Jackson & (12) \\
\hline B & $40(1)$ & PA-50623 & Poa annua & Pennsylvania & W. Uddin & This study \\
\hline B & $41(1)$ & CT-18 & Agrostis stolonifera & Connecticut & N. Jackson & (12) \\
\hline A & $42(1)$ & TX-26 & Agrostis stolonifera & Texas & N. Jackson & (12) \\
\hline A & $43(1)$ & VA-8977 & Poa аппиа & Virginia & $\ldots$ & This study \\
\hline A & $44(1)$ & ONT-99359 & Agrostis stolonifera & Ontario, Canada & T. Hsiang & This study \\
\hline A & $45(1)$ & $\mathrm{NH}-23$ & Agrostis stolonifera & New Hampshire & N. Jackson & (12) \\
\hline A & $46(1)$ & NJ-8467 & Pоа аппиа & New Jersey & $\ldots$ & This study \\
\hline A & $47(5)$ & NJ-7130 & Agrostis stolonifera & New Jersey & $\ldots$ & This study \\
\hline A & $47(5)$ & NJ-8400 & Lolium perenne & New Jersey & $\ldots$ & This study \\
\hline A & $47(5)$ & NJ-RWCC & Poa annua & New Jersey & $\ldots$ & This study \\
\hline A & $47(5)$ & NJ-HF2B & Agrostis stolonifera & New Jersey & $\ldots$ & This study \\
\hline A & $47(5)$ & PA-211 & Poa annua & Pennsylvania & W. Uddin & This study \\
\hline B & $48(1)$ & NJ-6553 & Роа аппиа & New Jersey & $\ldots$ & This study \\
\hline B & $49(1)$ & $\mathrm{CT}-27$ & Agrostis stolonifera & Connecticut & N. Jackson & (12) \\
\hline B & $50(1)$ & NY-16 & Agrostis stolonifera & New York & N. Jackson & This study \\
\hline$\cdots$ & $51(1)$ & $\begin{array}{l}\text { NJ-10BB } \\
\text { (outgroup) }\end{array}$ & $\begin{array}{l}\text { Vaccinium corymbosum } \\
\text { (C. acutatum) }\end{array}$ & New Jersey & P. Oudemans & This study \\
\hline $\mathrm{C}$ & $52(1)$ & $\mathrm{S} 3001$ & $\begin{array}{l}\text { Sorghum bicolor } \\
\text { (C. sublineolum) }\end{array}$ & Burkina Fasso & L. Vaillancourt & $(67)$ \\
\hline $\mathrm{D}$ & $53(1)$ & NY-15182 & Zea mays & New York & G. Bergstrom & This study \\
\hline $\mathrm{C}$ & $54(2)$ & $\mathrm{S} 12001$ & Sorghum bicolor & Brazil & L. Vaillancourt & (67) \\
\hline $\mathrm{C}$ & $54(2)$ & S19001 & Sorghum bicolor & South Africa & L. Vaillancourt & $(25)$ \\
\hline $\mathrm{C}$ & $55(1)$ & S17001 & Sorghum bicolor & Texas & L. Vaillancourt & (25) \\
\hline $\mathrm{D}$ & $56(2)$ & MO-478 & Zea mays & Missouri & L. Vaillancourt & This study \\
\hline $\mathrm{D}$ & $56(2)$ & MO-978 & Zea mays & Missouri & L. Vaillancourt & This study \\
\hline $\mathrm{D}$ & $57(18)$ & BZ-500190 & Zea mays & Brazil & L. Vaillancourt & (67) \\
\hline $\mathrm{D}$ & 57 (18) & IN-10472 & Zea mays & Indiana & L. Vaillancourt & This study \\
\hline $\mathrm{D}$ & 57 (18) & IN-10570 & Zea mays & Indiana & L. Vaillancourt & This study \\
\hline $\mathrm{D}$ & 57 (18) & IN-10670 & Zea mays & Indiana & L. Vaillancourt & This study \\
\hline $\mathrm{D}$ & 57 (18) & IN-10970 & Zea mays & Indiana & L. Vaillancourt & This study \\
\hline $\mathrm{D}$ & 57 (18) & IN-12270 & Zea mays & Indiana & L. Vaillancourt & This study \\
\hline $\mathrm{D}$ & $57(18)$ & IN-12475 & Zea mays & Indiana & L. Vaillancourt & This study \\
\hline $\mathrm{D}$ & 57 (18) & IN-300170 & Zea mays & Indiana & L. Vaillancourt & This study \\
\hline $\mathrm{D}$ & 57 (18) & IN-DUB90 & Zea mays & Indiana & L. Vaillancourt & This study \\
\hline $\mathrm{D}$ & 57 (18) & KY-197 & Zea mays & Kentucky & L. Vaillancourt & This study \\
\hline $\mathrm{D}$ & 57 (18) & KY-297 & Zea mays & Kentucky & L. Vaillancourt & This study \\
\hline $\mathrm{D}$ & $57(18)$ & KY-397 & Zea mays & Kentucky & L. Vaillancourt & This study \\
\hline $\mathrm{D}$ & $57(18)$ & KY-398 & Zea mays & Kentucky & L. Vaillancourt & (25) \\
\hline $\mathrm{D}$ & 57 (18) & MO-178 & Zea mays & Missouri & L. Vaillancourt & This study \\
\hline $\mathrm{D}$ & 57 (18) & MO-878 & Zea mays & Missouri & L. Vaillancourt & This study \\
\hline $\mathrm{D}$ & 57 (18) & MO-1001178 & Zea mays & Missouri & L. Vaillancourt & This study \\
\hline $\mathrm{D}$ & $57(18)$ & NC-200170 & Zea mays & North Carolina & L. Vaillancourt & This study \\
\hline $\mathrm{D}$ & 57 (18) & NY-AU80 & Zea mays & New York & L. Vaillancourt & (25) \\
\hline $\mathrm{D}$ & 57 (18) & NY-400180 & Zea mays & New York & L. Vaillancourt & This study \\
\hline $\mathrm{D}$ & $58(1)$ & IN-D77 & Zea mays & Indiana & L. Vaillancourt & This study \\
\hline $\mathrm{D}$ & $59(1)$ & IN-900190 & Zea mays & Indiana & L. Vaillancourt & This study \\
\hline
\end{tabular}


PAUP* version $4.0 b 10$ (63) and, after excluding the burn-in, a $75 \%$ majority-rule consensus tree was constructed, with the percentage of samples recovering a particular clade representing that clade's posterior probability (33). Bayesian posterior probabilities correspond to the statistical probability that a clade is present in the true tree, given the specified priors, the likelihood model, and the data examined $(33,39)$; a final $75 \%$ consensus tree was then generated from all trees in the posterior distribution sampled from the three runs (83,539 trees).

MP analyses were performed using PAUP* under the heuristic search option, with starting trees obtained from 100 randomaddition replicates, and using a tree-bisection reconnection (TBR) branch swapping strategy. Multiple MP trees for any data set were combined into single strict consensus trees. Nonparametric bootstrap resampling was conducted to evaluate relative levels of support for individual nodes (27) using 1,000 bootstrap pseudoreplicates with 100 random additions and TBR branch swapping. MP analyses were conducted for both the individual data sets and the total combined data set.

Estimating recombination and its impact on phylogenetic inference. Although $C$. graminicola is thought to reproduce in nature almost exclusively by clonally generated conidia, populations of this fungus still may be structured to some extent by recombination, either through historical events or through the exchange of genetic material by means of vegetative anastomosis between different individuals. Since the presence of recombination has the potential to produce conflicting phylogenetic signal, and may lead to incorrect evolutionary inferences, we investigated whether relationships between the $C$. graminicola taxa are more accurately represented by a reticulating network rather than a bifurcating phylogenetic tree topology. First, topologies of individual gene genealogies and the multilocus gene tree were visually inspected for the presence of incongruence suggestive of recombination. To detect recombination events not reflected in the tree topology, a combination of methods that use substitution patterns and site incompatibility to infer the presence of conflicting signal were employed. After removing indels from the aligned multilocus data set, sequences were collapsed into unique haplotypes using SNAP Map and SITES version 1.1 (29) launched through SNAP Workbench (51). Since the majority of the ingroup taxa in our analyses are likely to be recently diverged, all sites violating the infinite sites model, which assumes that the possibility of multiple mutations at a single nucleotide site can be ignored due to extremely low mutation rates, were eliminated. The resultant haplotype data set was used to identify the presence of reticulating relationships inappropriately represented in an acyclic tree topology; such relationships would be generated by evolutionary processes acting at the population level such as hybridization between lineages or recombination between genes, or homoplasic events such as convergent, parallel, or reverse mutations. We used the split decomposition network method, a transformation-based approach that uses distance parsimony to partition data sets into "splits" of sequences (8). The splits are combined successively, with any incompatible, contradictory groupings introducing a loop into the network to indicate the conflict. We employed the computer program SplitsTree version 4.0 b14 (35) to visualize reticulation networks in the data set, with branch support estimated by performing 10,000 bootstrap pseudoreplicates. In the split-graph network, reticulating taxa will be connected by more than one branch, with each connection representing alternative solutions; if the data are perfectly phylogenetic, a bifurcating tree topology will result.

To explore further the boundary between hierarchal and nonhierarchal, tokogenetic relationships in our sample, a site compatibility matrix was generated from the haplotype data set using the SNAP Clade and SNAP Matrix functions of SNAP Workbench. The compatibility matrix was used to identify the presence of compatibility/incompatibility among the haplotypes, with any resultant incompatible sites removed from the data set. The data set was also evaluated for the signature of recombination events by using Hudson's four gamete test (32) executed in DnaSP (53); any sites identified as potentially recombinant were also excluded from the matrix. The resultant haplotype data set, with any potentially confounding recombinant or homoplasic sites removed, was used to perform MP analysis in PAUP* to visualize those portions of the tree topology uniquely characterized by hierarchal, species-level relationships.

Morphological analysis. To determine if the fungi described in the present study as $C$. cereale conform to the morphological description established by Selby and Manns (54), we inspected syntype specimens from the Kansas State Herbarium, presently curated by the New York Botanical Garden Steere Herbarium (NYBG) (NYBG specimen numbers 305598 [type] and 276683 on Bromus secalinus; 305599 on Avena sativa [type]; 305595 on Arrhenatherum elatius [type]; 305596 [type] and 276680 on Secale cereale; 305597 [type], 276684 and 276681 on Triticum vulgare; 276686 on Dactylis glomerata; 276687 on Phleum pratense; 276685 on Agrostis alba; and unnumbered samples from Agrostis alba, Arrhenatherum elatius, and Poa pratensis). Morphological examination was also performed on Colletotrichum specimens isolated from pooid grasses in our collection (KS20BIG from Bromus inermis; ONT-00128, NY-16, CT-18, MA20, MA-21, MA-24, CT-25, and CT-27 from Agrostis stolonifera; NJ-6722, NJ-6795, CA-1715, NJ-4990, NH-23, NBR-13, RI-9, CT-8, MA-11, PA-50114, PA-WH3, PA-50623, PA-50231, PA5005, PA-50111, PA-50183, PA-4410, PA-V1, and PA-50002 from Poa annua; KS-20DGU and KS-20DGY from D. glomerata; NJ-CA1 from Calamagrostis acutifolia; and KS-20EVM from Elymus virginicanus), with cultures grown on PDA under constant light at $26^{\circ} \mathrm{C}$ for 7 to 10 days. Microscopic observations and measurements were made with an Olympus CX40 microscope with bright field or phase contrast illumination. At least 50 conidia from each isolate were measured; dimensions of other fungal structures are given as the range of at least 20 measurements where possible. Photomicrographs were obtained using an Olympus BX41 microscope equipped with a MagnaFire Digital Firewire camera and software (Optronics, Goleta, CA).

\section{RESULTS}

Data set characteristics and analysis. Because ribosomal DNA genes are maintained at high copy numbers in eukaryotic genomes, nonorthologous copies may potentially be present (46), violating the expectation of homology required to reconstruct phylogenetic relationships accurately. In the present study, two lines of evidence support the presence of only orthologous rDNA sequences: nucleotide base calling from the ITS rDNA chromatographs generated by sequencing directly from the PCR products was clean and unambiguous, and all three gene trees were concordant at main branch points and tip clades where phylogenetic signal is adequate to resolve such relationships.

Among members of the $C$. graminicola/C. cereale/C. sublineolum ingroup, few insertion-deletion events were observed in the nucleotide sequence alignments, and none of the gaps introduced rendered the ingroup problematic; ambiguous alignment was restricted to outgroup comparisons. The combined molecular data set comprised a total of 1,229 nucleotides, with 130 indels coded as standard characters (Table 2). Much of the coded indel data were autapomorphic only with respect to the outgroup taxa and were otherwise parsimony-informative between ingroup taxa; 8 indels of 2 to $4 \mathrm{bp}$ in length within introns were characteristic of particular monophyletic groupings recovered by the ingroup phylogeny.

Given the number of variable characters in the data sets, all three genes appeared to be potentially informative. A preliminary analysis of a 650 -bp region of the $T U B-2$ gene from the taxa NJ- 
6340, PA-50005, NJ-6491, MO-1001178, and NY-15182 showed only one variable character; therefore, it was not included in the phylogenetic reconstruction (data not shown). In particular, the 536-bp SOD2 sequence consists of $41 \%$ parsimony-informative characters within the ingroup taxa (ITS $=12 \%$; HMG $=12 \%$; combined $=25 \%$ ). Individual gene genealogies constructed using strict consensus trees under parsimony showed visually concordant topologies, although the HMG and ITS sequences were unable to recover some of the groups reconstructed by the more informative SOD2 and the combined data set due to their lower levels of phylogenetic signal. This relative lack of phylogenetic resolution from the $C$. graminicola ITS sequence is consistent with our previously published results (19) and a study conducted by Hsiang and Goodwin (31); similar reports have been made in other Colletotrichum species (7). The lower resolution exhibited by the ITS gene tree may also result to some degree from the extremely large number of equally parsimonious tree topologies recovered during the heuristic searches: 44,034 MP trees were inferred from the ITS sequence data $(\mathrm{HMG}=4 ; S O D 2=72)$.

To assess whether the ITS, HMG, and SOD2 sequences generate tree topologies that are congruent, we visually compared the individual gene genealogies for evidence of contradictory phylogenetic relationships. Although the incongruence length difference test (ILD; implemented as the partition length homogeneity test in PAUP) is still used in many phylogenetic studies to assess potential conflict among data sets, several properties of this test are known to generate misleading results, particularly when among-site rate variation is present $(9,21,23,24,57)$. Because this is the case in our study, the ILD is probably not a reliable method to determine congruence of data sets stringently. We therefore relied on visual inspection to evaluate congruence between the individual gene genealogies. We found only three isolates with inconsistent placement between the gene trees: MA-6722 from Poa annua grouped with $C$. cereale clade A for the SOD2 and combined trees, but with $C$. cereale clade B for the ITS and HMG; NJ-8467 from Poa annua grouped with $C$. cereale clade A for the ITS, HMG, and combined trees, but with $C$. cereale clade B for the SOD2 tree; and NY-15182 from Z. mays grouped with C. graminicola for the HMG, SOD2, and combined trees, but with the $C$. cereale lineage for the ITS tree. Aside from these three individuals, the three gene genealogies all recovered monophyletic groups of $C$. sublineolum, $C$. graminicola, and $C$. cereale taxa, were topologically congruent with one another at these main clades, and were also in agreement with population subdivisions recovered through an analysis of three transposable element restriction fragment length polymorphism (RFLP) patterns (J. Crouch, B. B. Clarke, and B. I. Hillman, unpublished data). The individual data sets were therefore combined and used for multilocus analysis.

Analysis of the three gene sequences using the AIC in the computer program Modeltest determined that the evolutionary signature of each sequence was best modeled separately for the Bayesian analyses (Table 3). Although the genes ultimately reconstruct the same relationships between the ingroup taxa, a distinct set of parameters uniquely characterizes the evolutionary processes experienced by each gene. In particular, all three gene sequences showed different rates of variation among different nucleotide sites (among-site rate variation). To correct for the presence of among-site rate variation in the data set, which can cause the number of unobserved, multiple substitutions to be underestimated, the $\alpha$ shape parameter from the gamma distribution was incorporated into the models for each gene (which were established as priors in the Bayesian ML analysis) with $\alpha$ inversely proportional to the amount of among-site rate heterogeneity (when rates are equal, $\alpha=$ infinity). Among-site rate heterogeneity in the SOD2 sequence was considerable $(\alpha=0.8737)$; heterogeneity present in the other genes was also estimated to be high (ITS, $\alpha=0.9962$; HMG, $\alpha=1.8284$ ).

In the Bayesian likelihood analyses, one run plateaued at 60,000 generations, the second after 119,000 iterations, and the third reached stationarity at 53,000 (ln likelihood values: run 1: -8785.664 to -8699.69 , average -8733.853 ; run 2 : -8826.63 to -8740.83 , average -8740.83 ; and run 3 : -8794.062 to -8658.552 , average -8697.4453 ). All three runs converged on the same topology, so all generations sampled from the posterior distribution were combined $(83,539$ trees) to produce a $75 \%$ consensus tree (Fig. 1) representing our hypothesis of descent for these taxa. The consensus tree had an ln likelihood score of $-8,746.140$; only clades with relatively strong support ( $>75 \%$ support for nodes from the posterior distribution) were retained.

Phylogenetic relationships. All phylogenetic analyses, separate and combined, using either the complete data set, the data set reduced to unique haplotypes, or the haplotype data set reduced to strictly compatible sites (83 total sites) resolved three distinct,

TABLE 2. Characteristics of the genomic regions used in this investigation

\begin{tabular}{|c|c|c|c|c|c|c|c|c|c|}
\hline Gene & $\begin{array}{l}\text { Exon } \\
\text { regions }\end{array}$ & $\begin{array}{l}\text { Intron } \\
\text { regions }\end{array}$ & $\begin{array}{c}\text { Nucleotide } \\
\text { characters, } \\
\text { excluding indels }\end{array}$ & $\begin{array}{l}\text { Coded } \\
\text { characters } \\
\text { (indels) }\end{array}$ & $\begin{array}{l}\text { Invariable } \\
\text { nucleotide } \\
\text { characters }^{\mathrm{a}}\end{array}$ & $\begin{array}{l}\text { Variable, parsimony } \\
\text { uninformative nucleo- } \\
\text { tide characters }{ }^{\mathrm{a}}\end{array}$ & $\begin{array}{l}\text { Parsimony infor- } \\
\text { mative nucleotide } \\
\text { characters }^{\mathrm{a}}\end{array}$ & $\begin{array}{l}\text { MP tree } \\
\text { length }\end{array}$ & $\begin{array}{l}\text { Number of } \\
\text { equally parsi- } \\
\text { monious trees }\end{array}$ \\
\hline ITS & 1 & 2 & 482 & 49 & 358 & 68 & $56(12 \%)$ & 357 & 44,034 \\
\hline SOD & 3 & 2 & 536 & 38 & 504 & 0 & $221(41 \%)$ & 518 & 72 \\
\hline Combined data set & 6 & 5 & 1,229 & 130 & 1,032 & 82 & $303(25 \%)$ & 1,058 & 8,813 \\
\hline
\end{tabular}

${ }^{a}$ Parsimony informative characterization of data set considers ingroup taxa only, outgroups are excluded.

TABLE 3. Best fit evolutionary models used in Bayesian analysis as determined by the Akaike information criterion (AIC) in Modeltest

\begin{tabular}{|c|c|c|}
\hline $\begin{array}{c}\text { ITS1/5.8S/ITS2 } \\
482 \text { nucleotide characters }\end{array}$ & $\begin{array}{l}\text { HMG }(M A T 1-2) \\
211 \text { nucleotide characters }\end{array}$ & $\begin{array}{c}\text { SOD2 } \\
536 \text { nucleotide characters }\end{array}$ \\
\hline $\begin{array}{c}\mathrm{SYM}+\mathrm{G} \\
\mathrm{A} \rightarrow \mathrm{C} 1.0161 \\
\mathrm{~A} \rightarrow \mathrm{G} 1.2515 \\
\mathrm{~A} \rightarrow \mathrm{T} 1.0096 \\
\mathrm{C} \rightarrow \mathrm{G} 1.7520 \\
\mathrm{C} \rightarrow \mathrm{T} 2.7189 \\
\mathrm{G} \rightarrow \mathrm{T} 1.000 \\
\ldots \\
\text { Invariable }=0 \\
\text { Gamma } \\
\alpha=0.9962 \\
\end{array}$ & $\begin{array}{c}\mathrm{HKY}+\mathrm{G} \\
\text { Frequency } \mathrm{A}=0.305 \\
\text { Frequency } \mathrm{C}=0.269 \\
\text { Frequency } \mathrm{G}=0.224 \\
\text { Frequency } \mathrm{T}=0.201 \\
\ldots \ldots \\
\ldots . \\
\text { Ti/Tv ratio }=1.2350 \\
\text { Invariable }=0 \\
\text { Gamma } \\
\alpha=1.8284\end{array}$ & $\begin{array}{c}\mathrm{HKY}+\mathrm{G} \\
\text { Frequency } \mathrm{A}=0.2352 \\
\text { Frequency } \mathrm{C}=0.2575 \\
\text { Frequency } \mathrm{G}=0.3088 \\
\text { Frequency } \mathrm{T}=0.1986 \\
\ldots \\
\ldots \\
\text { Ti/Tv ratio }=1.5889 \\
\text { Invariable }=0 \\
\text { Gamma } \\
\alpha=0.8737\end{array}$ \\
\hline
\end{tabular}




\section{KEY TO HOST PLANT ORIGIN}

Agrostis canina

Agrostis stolonifera

Bromus inermis

Calamagrostis acutifolia

Dactylis glomerata

(2) Elymus canadensis

$\bigcirc$ Elymus virginicanus

Poa annua

$\sum$ Poa pratensis

Sorghum bicolor

$\checkmark$ Zea mays
Lolium perenne

Scale Bar:

0.1 nucleotide substitutions per site

$r$
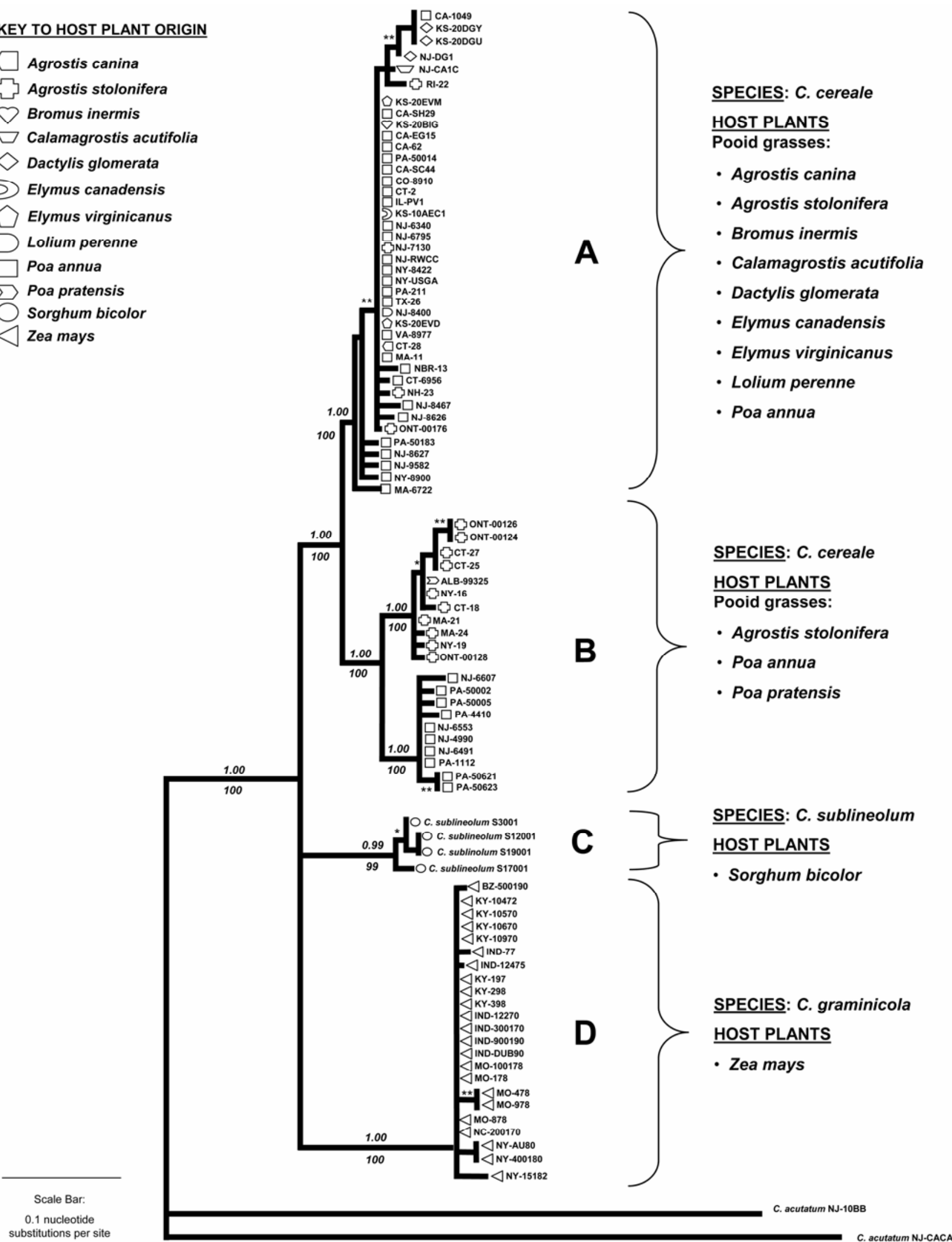

HOST PLANTS

Pooid grasses:

- Agrostis canina

- Agrostis stolonifera

- Bromus inermis

- Calamagrostis acutifolia

- Dactylis glomerata

- Elymus canadensis

- Elymus virginicanus

- Poa annua

c. cereale

HOST PLANTS

id grasses:

Poa pratensis

SPECIES: C. sublineolum

HOST PLANTS

- Sorghum bicolor

C. acutatum NJ-CACA
SPECIES: C. cereale

- Lolium perenne

Fig. 1. Seventy-five percent majority rule Bayesian maximum likelihood phylogenetic tree constructed from the 83,539 trees sampled from the posterior distribution representing the well-supported hypothesis of descent recovered in the multilocus sequence analysis. The scale bar indicates divergence, measured in nucleotide changes per site. All groups illustrated by this tree are supported by posterior probabilities of at least 0.75 . Posterior probabilities supporting the topology are shown above the nodes where space permits; elsewhere on the tree two asterisks were supported by posterior probabilities of $>99 \%$; branches with one asterisk were supported by posterior probabilities of $>95 \%$. Maximum parsimony analysis also recovered this same basic phylogeny; bootstrap values from 1,000 pseudoreplicates are shown below the nodes. Symbols next to taxa indicate host plant origin; the key to host plant origin is to the left of the phylogeny. 
well-supported groups: (i) a monophyletic group comprising isolates from Pooideae grasses (clades A and B, Fig. 1), (ii) a group comprising isolates from sorghum $(C$. sublineolum, clade C), and (iii) a group comprising isolates from maize (clade D). In the SOD2 and the multilocus tree, a further subdivision was observed: the $C$. cereale clade subdivided into unique lineages (clades A and B). C. cereale clade B further diverged into two smaller groupings. These groups were supported by both bootstrap values and posterior probabilities greater than $95 \%$. The phylogenetic trees recovered under both parsimony and Bayesian likelihood optimality criteria are in agreement at all of the main clades. Figure 1 shows the $75 \%$ consensus tree constructed from the 83,539 trees sampled from the Bayesian posterior distribution; both the posterior probabilities and bootstrap support values are plotted at the nodes (the MP tree is not illustrated separately due to topological congruence with the ML phylogeny; groups not supported by at least a value of 0.75 by both bootstrap and posterior probabilities were collapsed). The results of the molecular phylogenetic analysis reconstructs a species history characterized by the presence of morphologically similar sister species: C. graminicola, which is pathogenic to corn, and a group of C. cereale lineages found on a wide range of pooid grasses, including cultivated $\mathrm{C} 3$ turfgrasses.

A much less well-supported association between $C$. graminicola and $C$. sublineolum was consistently recovered in all of the phylogenetic analyses, with these two species always forming a monophyletic group, separate from the $C$. cereale group. This association between the cereal-derived lineages was not, however, entirely well supported, with a posterior probability of only 0.63 in the Bayesian consensus tree. Analysis of the haplotype data set using the split decomposition network reconstruction method (Fig. 2) also estimates a close relationship between $C$. graminicola and $C$. sublineolum, but confidence in a recent common ancestry for these taxa was extremely low (bootstrap = 56).

Reticulation and incompatibility in the data set. A total of 57 unique multilocus haplotypes were identified from the ingroup sample, with 611 nucleotides distinctively establishing the haplotypes after the removal of introns and any positions violating the infinite sites model. The split-decomposition splits-graph used to visualize the presence of reticulate evolution in the haplotype data set (Figs. 2 and 3) recovered tree-like relationships between the main species clades also estimated by the phylogenetic investigation: C. sublineolum from sorghum, C. graminicola from corn, and the $C$. cereale species group from the subfamily Pooideae grasses. Within the clades, on the intraspecific level, a reticulating network of relationships clearly emerged: a single loop was present among the C. graminicola haplotypes (five haplotypes, 23 individuals), a single loop connected the $C$. sublineolum haplotypes (three haplotypes, four individuals), and more complex patterns were found individually among the $C$. cereale lineages (Fig. 3). The two main $C$. cereale phylogenetic clades A and B were inferred in the splits-graph, with reticulate lineages occurring only below the level of these groups. $C$. cereale clade A consisted of 27 unique haplotypes from 59 individuals, all radiating from haplotype $5(\mathrm{H} 5)$, which, given its central position in the splitsgraph, is likely the ancestral haplotype for the $C$. cereale lineages. This interpretation is further supported by the observation that $\mathrm{H} 5$ contained the largest number of $C$. cereale isolates (22), and was widely distributed throughout the entire range of our sample. The majority of the haplotypes were tightly interrelated in clade A,

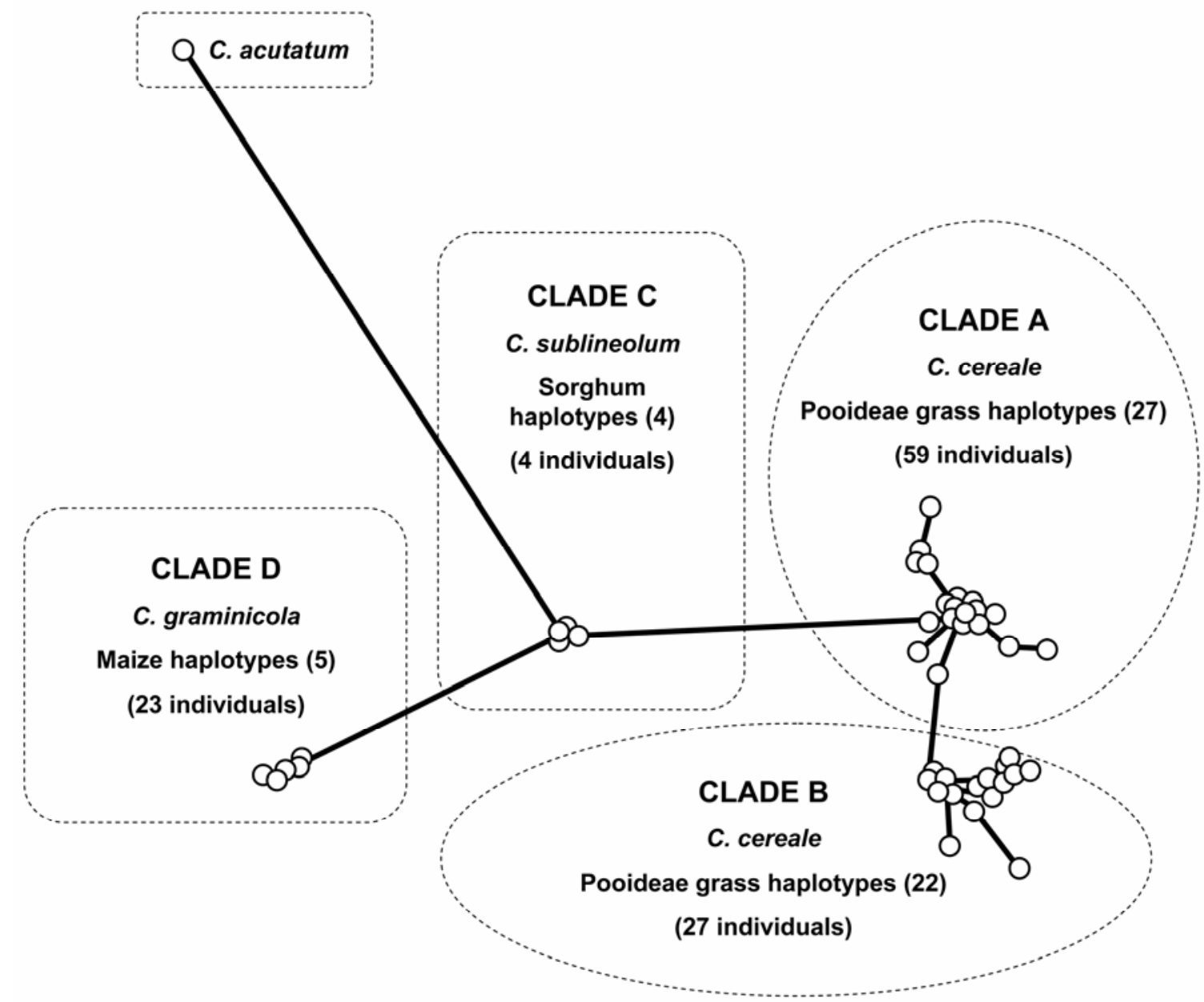

Fig. 2. Evolutionary relationships between the sampled taxa, inferred using split-decomposition network analysis as described in the text. 


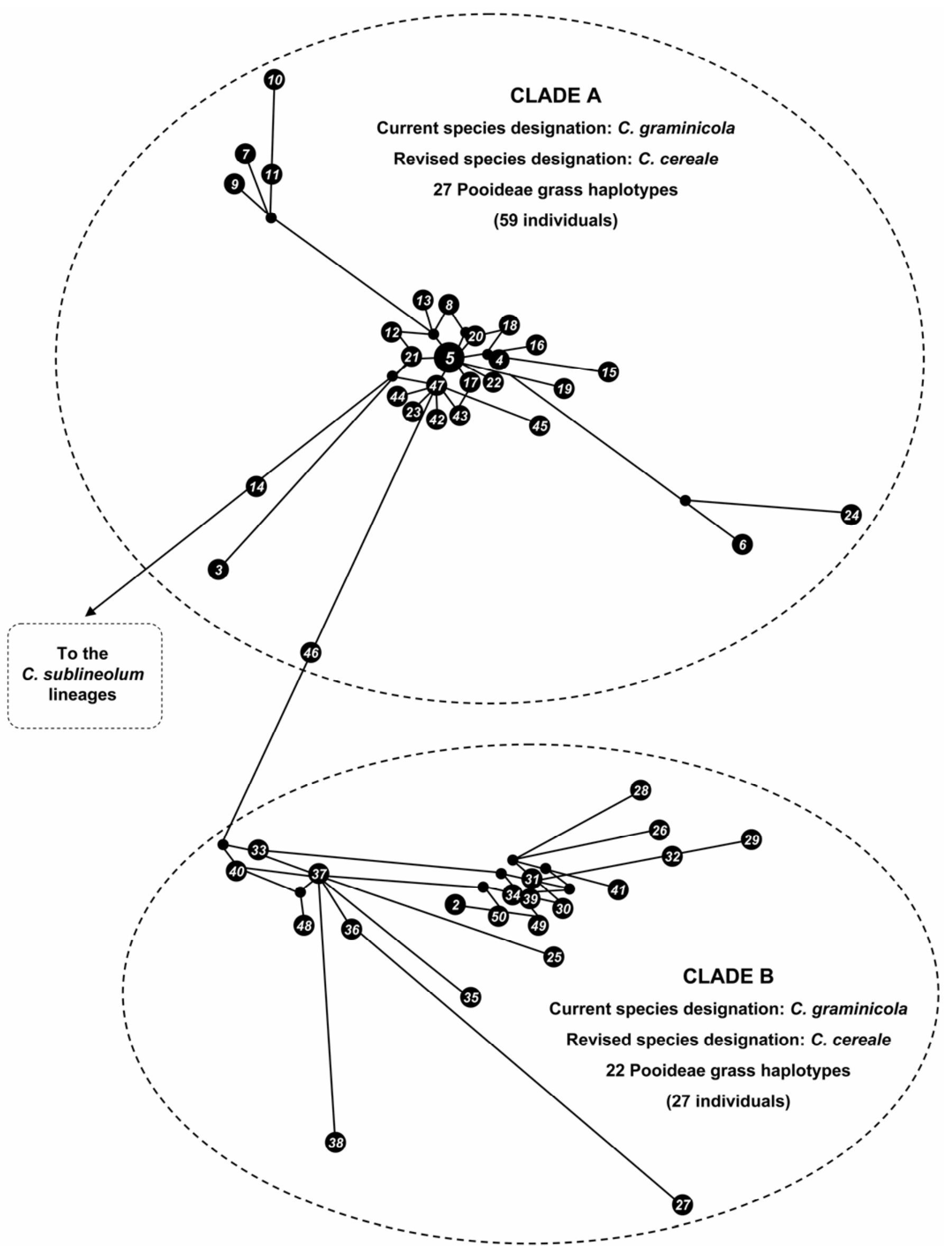

Fig. 3. An enlarged view of the splits-graph topology (Fig. 2), illustrating Colletotrichum cereale clades A and B. The small filled circles represent the positions of inferred intermediate haplotypes. 
with only a few divergent lineages. Based upon its position within the splits-graph, clade A haplotype 47 also appeared to be a central lineage among the group, and served as the connecting point between $C$. cereale clades A and B. Haplotype 46, represented by $C$. cereale isolate NJ-8467 from Poa annua, was positioned directly between clades $\mathrm{A}$ and $\mathrm{B}$, which is consistent with the observed conflict between gene genealogies for this isolate (ITS, HMG, and multilocus = clade A; SOD2 = clade B). Collectively, these data suggest that this haplotype is a hybrid between the two $C$. cereale lineages. Haplotype 3 , consisting of $C$. cereale isolate MA-6722, while similarly characterized by conflicting gene trees in the phylogenetic analyses (SOD2 and multilocus tree = clade A; ITS and HMG = clade B), appears in the splitsgraph to be a highly divergent taxon, but uniquely a member of the clade A lineage.

The haplotypes of $C$. cereale clade $\mathrm{B}$, although numerically less prevalent in our sample, were nevertheless a much more genetically diverse assemblage, with 22 haplotypes resulting from 27 isolates interwoven into a complex pattern of cycles. While the phylogenetic analyses support the split of clade B into two distinct lineages, the splits-graph was unable to recover the subdivision, suggesting that these taxa are all of the same species.

Analysis of the haplotype data set by means of the compatibility matrix and Hudson's four gamete test identified the majority of characters as being incompatible; these characters were subsequently removed from the data set. The resultant 83 character data set was used to further investigate species-level boundaries through MP phylogenetic analysis. This reduced MP phylogeny (data not shown) confirmed the splits-graph topology: $C$. sublineolum from sorghum, $C$. graminicola from corn, and $C$. cereale from the Pooideae grasses are each individual species; however, the species level divergence of $C$. cereale clades A and B found in all other analyses was not recovered.

Taxonomy. Based upon the unique patterns of fixed nucleotide differences in DNA sequence data at the ITS1/5.8S/ITS2, MAT1-2, and SOD2 nuclear loci, it is evident that Colletotrichum isolated from the pooid grasses examined in this study form a species taxon distinct from C. graminicola, which is limited to the fungus pathogenic to maize host plants. Based upon these nucleotide data, we formally propose to resurrect and emend the species C. cereale and to emend the species descriptions of C. graminicola and C. sublineolum.

Colletotrichum cereale Manns, Ohio Agric. Exp. Stn. Bull. 203:207 (1909).

Teleomorph. Unknown.

Emended description. Inhabits grasses of the subfamily Pooideae; pathogenic and sometimes particularly aggressive on Poa annua, Poa pratensis, P. sapina, Agrostis stolonifera, Agrostis canina, and Lolium perenne. C. cereale is uniquely described by the following fixed nucleotide characters (positions are relative to the nucleotide sequence alignment of the epitype specimens): ITS1/5.8S/ITS2 positions $15(\mathrm{C}), 39(\mathrm{~T}), 56(\mathrm{C}), 98(\mathrm{C}), 104(\mathrm{C})$, $117(\mathrm{G}), 145$ (C), $165(\mathrm{~A}), 178(\mathrm{~T}), 409$ (A), 517 (T), 522 (C); MAT1-2 positions 2 (A), $54(\mathrm{C}), 79(\mathrm{~A} / \mathrm{T}), 87(\mathrm{G}), 97(\mathrm{~A}), 101$ (C), 109 (A), 123 (T), 129 (G), 131 (A), 154 (C), 163 (C), 172 (A), 199 (A); and SOD2 positions 35 (C/T), 45 (A), 47 (C), 53 (A), $58(\mathrm{~A}), 61(\mathrm{G}), 70(\mathrm{C}), 73(\mathrm{~A}), 77(\mathrm{~T}), 88(\mathrm{C}), 119(\mathrm{G}), 127$ (C), 133 (C), 136 (G), 142 (C), 151 (C), 169 (A), 175 (C), 205 (C), 211 (C), 226 (G), 244 (A), 247 (C), 259 (C), 262 (C), 268 (C), 280 (T), 292 (G), 332 (G), 355 (C), 373 (G/A), 376 (C), 382 (C), 386 (G), 394 (T), 403 (C), 451 (C), 454 (C), 455 (G), 500 (T), $501(\mathrm{G}), 512(\mathrm{C}), 518(\mathrm{~T}), 519(\mathrm{~T}), 520(\mathrm{G}), 521(\mathrm{G}), 522$ (A), $525(\mathrm{G}), 534(\mathrm{~A}), 537$ (C), 541 (C), 545 (T), 546 (T), 547 (C), $551(\mathrm{C}), 558(\mathrm{~T})$, and $571(\mathrm{G})$.

Colonies on PDA under constant illumination highly variable; usually form dark mat of tight setae masses across agar surface; commonly heavy conidia accumulation gives orange cast to brown/black culture. Some cultures exhibit thin layer of hyphae along agar surface, copious amounts of conidia give orange appearance. Some cultures possess fluffy aerial mycelium growing over setae, producing gray appearance; generally as colonies age mycelia overtakes entire culture surface. Hyphae septate, normally hyaline, sometimes dark brown when present at the base of setae, 1.0 to $6.5 \mu \mathrm{m}$, often guttulate. Conidia falcate or fusiform, apices acute, individually hyaline but appear salmon-orange en mass, may be mono-, bi-, or up to seven-guttulate or oil drops may be absent from the cytoplasm, measuring 6.0 to $33.8 \mu \mathrm{m} \times 2.2$ to $6.3 \mu \mathrm{m}$ with an average of $23.3 \mu \mathrm{m} \times 3.4 \mu \mathrm{m}$. Germinating conidia
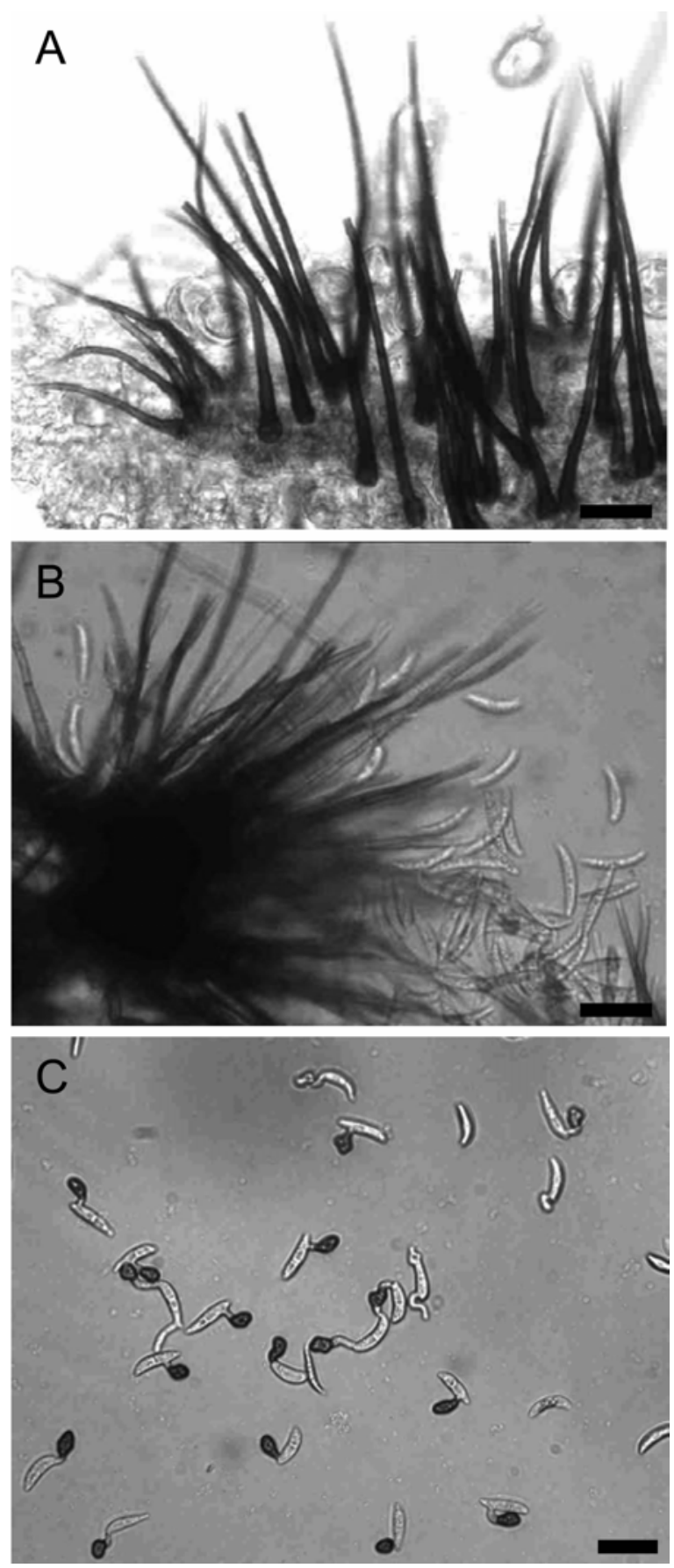

Fig. 4. Colletotrichum cereale morphological structures $($ Bar $=25 \mu \mathrm{m})$. A, Heavily melanized setae emerging from an acervulus on the leaf of Bromus secalinus from the lectotype specimen (NYBG-305598); B, setae and conidia, grown on potato dextrose agar from epitype strain KS-20BIG; and C, germinating conidia, with the formation of germ tubes generally (but not always) leading to the formation of heavily melanized appressoria. 
form single or infrequently two hyaline germ tubes that terminate in dark brown/black appressoria, sometimes appressoria absent; germ tubes separated from appressoria by septa (Fig. 4), occasionally appressoria forms directly from conidia. Appressoria rounded and smooth or irregular or lobate or multi-lobate, measuring 8.5 to $11.6 \mu \mathrm{m} \times 6.5$ to $10.2 \mu \mathrm{m}$. Setae develop from dark brown, tight masses of hyphae (Fig. 4); in culture dense, rounded masses of setae form, (Fig. 4) sometimes partly or completely covered in thick deposition of conidia. Individual brownblack setae separated from hyphae by septa. Setae base swollen or not swollen, irregularly septate with up to 7 septa, measuring 32 to $120 \mu \mathrm{m} \times 6$ to $8 \mu \mathrm{m}$ at base, tapering at tip.

Type specimen. Examination of herbarium syntype specimens confirmed the presence of acervuli on the grass hosts, in association with black-brown setae that are characteristic of Colletotrichum. Very few conidia were observed; those that were present were somewhat shriveled and without cytoplasmic contents, falcate in shape, measuring 20 to $25 \mu \mathrm{m} \times 3 \mu \mathrm{m}$. Morphological comparison of the syntypes of $C$. cereale and the published descriptions and illustrations against our recent samples obtained from pooid grasses confirmed that the Colletotrichum isolated from pooid grasses in the present study are within the range of morphological variation consistent with the $C$. cereale species description. Although we attempted to extract DNA from the herbarium material, we were not successful, as the fungal tissue was in close association with the plant tissue, and relatively little fungal tissue was present. Attempts to revive the specimens on PDA were also unsuccessful; therefore comparisons of contemporary Colletotrichum strains with syntype specimens are necessarily confined to morphological estimations. Four of the New York Botanical Garden specimens were catalogued in the herbarium database as type specimens (although the published description never makes such a specification): 305598 on Bromus secalinus, 305599 on Avena sativa, 305595 on Arrhenatherum elatius, 305596 on Secale cereale, and 305597 on Triticum vulgare. A holotype was not designated; we therefore establish 305598 (Bromus secalinus) as the lectotype for the species, and $305599,305595,305596$, and 305597 are specified as paratypes. To facilitate species interpretation using the molecular characters described in this study, we designate KS-20BIG, NJ-6795, PA5062-3, and NJ-4990 as epitypes; cultures of the epitype strains have been deposited in the American Type Culture Collection (ATCC), Manassas, VA, and the Centraalbureau voor Schimmelcultures (CVS), Utrecht, the Netherlands.

Comments. $C$. cereale also possesses several fixed autapomorphic characters that serve to uniquely distinguish the species from C. graminicola (positions are relative to the nucleotide sequence alignment of the epitype specimens): ITS1/5.8S/ITS2 positions 54 (no base), 69-72 (no bases), 100 (C), 111 (A), 115 (G), 121 (no base), 158 (no base), 404-406 (no bases), 525 (no bases); MAT1-2 positions 115 (no base), $120(\mathrm{G})$; and SOD2 positions 18-19 (AA), 25-27 (no bases), 29 (T), 56 (A), 60 (no base), 78 (no base), 82 (no base), 85 (T), 503 (no base), 508 (T), 562 (A), and 567 (no base).

In general, $C$. cereale is morphologically very similar to C. graminicola. Two continuous morphological characters (conidia length and hyphopodium area) have recently been suggested to differentiate approximately between $C$. graminicola and $C$. cereale $(12,25)$; however, the variability and overlap of range in these types of quantitative characters precludes diagnosis of these taxa uniquely and consistently on this basis (61). Conidia in these two species are sometimes different in length, with the conidia of C. graminicola typically, but not always, larger than those from C. cereale $(6,12,25,54$, our data); overall, C. cereale conidia grown on PDA measured 6.0 to $33.8 \mu \mathrm{m}$, while $C$. graminicola conidia ranged from 13.0 to $44.0 \mu \mathrm{m}$. Hyphopodium (mycelial appressoria) area is also notably different in the two species $(12,25)$, with the hyphopodium area of $C$. graminicola, on average, significantly larger than those of $C$. cereale, but this continuous character also is present in overlapping ranges $(C$. cereale 63.8 to $315.6 \mu \mathrm{m}^{2}$ and $C$. graminicola 136.7 to $\left.1,027 \mu \mathrm{m}^{2}\right)(12,25,61)$.

Colletotrichum graminicola (Ces.) G.W. Wilson, Phytopathology 4:110 (1914) (as "graminicolum").

$\equiv$ Dicladium graminicola Ces., Flora 35:398 (1852) (as "graminicolum").

$\equiv$ Vermicularia graminicola (Ces.) Westd., Bull. Acad. Roy. Brux. 12: n. 7 (1861).

$\equiv$ Steirochaete graminicola (Ces.) Sacc. Syll. Fung. 4:316 (1886).

$\equiv$ Colletotrichum zeae Lobik, Trudy severo-kavkazskogo Instituta Zashchity Rastenii 1(2):39 (1933).

$\equiv$ Colletotrichopsis graminicola (Ces.) Muntaola, Rev. Argent. Agron. 19:220 (1952).

$\equiv$ Colletotrichum graminicola f. sp. zeae Messaien, Lafon \& Malot, Ann. Epiphyt., ser. C., 10:454 (1959).

Teleomorph. Glomerella graminicola Politis, Mycologia 67:5672 (1975).

Emended description. Parasitic on Zea mays. C. graminicola is uniquely distinguished by the following synapomorphic fixed nucleotide characters (positions are relative to the nucleotide sequence alignment of the epitype specimens): ITS1/5.8S/ITS2 positions $15(\mathrm{~T}), 39(\mathrm{C}), 56(\mathrm{~T}), 92(\mathrm{G}), 98(\mathrm{C}), 99(\mathrm{~A}), 104(\mathrm{~T}), 117$ (C), $145(\mathrm{~T}), 165(\mathrm{G}), 178(\mathrm{C}), 409$ (T), $517(\mathrm{C}), 522$ (T); MAT12 positions $2(\mathrm{~T}), 54(\mathrm{~T}), 79(\mathrm{G}), 87(\mathrm{~A}), 97(\mathrm{G}), 101(\mathrm{~T}), 109(\mathrm{G})$, 123 (C), 129 (A), 131 (C), 154 (T), 163 (T), 172 (G), 199 (G); and SOD2 positions $35(\mathrm{~A}), 45(\mathrm{G}), 53(\mathrm{~T}), 58(\mathrm{~T}), 61(\mathrm{~A}), 70$ (G), 73 (G), 77 (C), 88 (T), 119 (A), 127 (T), 133 (T), 136 (A), 142 (G), 151 (T), 169 (G), 175 (A), 205 (T), 211 (A), 226 (T), 244 (T), 247 (T), 259 (T), 262 (G), 268 (A), 292 (C), 332 (A), $255(\mathrm{~T}), 373(\mathrm{~T}), 376(\mathrm{~T}), 382(\mathrm{~T}), 386(\mathrm{~A}), 394(\mathrm{C}), 403(\mathrm{~T}), 451$ (T), 454 (T), 455 (A), 500 (C), 501 (A), 512 (T), 518 (A), 519 (A), 520 (A), 521 (A), 522 (G), 525 (A), 534 (G), 537 (A), 541 (T), $545(\mathrm{~A}), 546(\mathrm{~A}), 547(\mathrm{~T}), 551(\mathrm{~T}), 558(\mathrm{C})$, and $571(\mathrm{~A})$.

Epitype establishment. The lectotype established for this species was examined by Sutton (58) from Z. mays (IMI83255). To facilitate species interpretation using the molecular characters described in this study, we designate MO-100178 from Z. mays (also known as $C$. graminicola isolate M1.001) as an epitype; a culture of this specimen has been deposited in the ATCC and the CVS.

Comments. The reader is referred to any of several excellent morphological studies of $C$. graminicola sensu stricto Sutton that have been published $(10,25,58-62)$. In general, $C$. graminicola is morphologically quite similar to $C$. cereale except for the two continuous quantitative conidial and hyphopodial characters noted above, but the overlapping range of these morphological characters precludes their usage for consistent and unique diagnosis of these species.

C. graminicola also possesses several fixed autapomorphic characters that can serve to uniquely distinguish the species from C. cereale (positions are relative to the nucleotide sequence alignment of the epitype specimens): ITS1/5.8S/ITS2 positions 54 (T), 69-72 (TCCG), 100 (no base), 111 (no base), 115 (no base), 121 (G), 158 (A), 404-406 (GTA), 525 (C); MATl-2 positions 115 (C), 120 (no base); and SOD2 positions 18-19 (no bases), 25-27 (AAC), 29 (no base), 47 (no base), 56 (no base), 60 (T), 78 (C), 82 (C), 85 (no base), 500 (C), 508 (no base), 562 (no base), and 567 (C).

Colletotrichum sublineolum Henn. apud Kabat \& Bub. Fungi imp. exs. 186 (1905) (as "sublineola").

$\equiv$ Colletotrichum graminicola f. sp. sorghi Messaien, Lafon \& Malot, Ann. Epiphyt., ser C., 10:456 (1959).

Colletotrichum graminicola var. zonatum Rajasab \& Ramal., Curr. Sci. 50(1):34 (1981).

Teleomorph. Unknown. 
Emended description. Parasitic on Sorghum bicolor and Sorghum halapense. C. sublineolum is uniquely distinguished by the following synapomorphic fixed nucleotide characters (positions are relative to the nucleotide sequence alignment of the epitype specimens): ITS1/5.8S/ITS2 positions 39 (T), 67 (T), 93 (C), 98 (T), 99 (C), 105 (C), 112 (C), 131 (G) 132 (A), 133 (G), 135 (A), 136 (T), 137 (A), 139 (G), 142 (A), 143 (A), 147 (T), 178 (T), 417 (T), 419 (A), 420 (C); MAT1-2 positions $2(\mathrm{~A}), 54(\mathrm{C}), 66$ (T), 77 (A) 79 (A) 87 (G), 88 (A), 95 (G), 106 (G), 130 (A), 145 (A), $154(\mathrm{C}), 163(\mathrm{C}), 181(\mathrm{~T}), 202(\mathrm{~T})$; and SOD2 positions 40 (C), 42 (T), 44 (T), 48 (T), 88 (C), $115(\mathrm{~A}), 125(\mathrm{G}), 142(\mathrm{C}), 148$ (A), 151 (C), 166 (T), 175 (C), 184 (T), 187 (A), 205 (C), 211 (C), 226 (G), 244 (A), 268 (C), 332 (G), 355 (C), 367 (A), 373 (G), 376 (C), 382 (C), 386 (C), 403 (C), 408 (T), 455 (G), 457 (C), 460 (A), 495 (A), 498 (G), 504 (G), 505 (G), 509 (T), 512 (G), 518 (G), 519 (G), 524 (A), 530 (G), 534 (A), 537 (T), 538 (C), $541(\mathrm{G})$, and $563(\mathrm{~A})$.

Epitype establishment. To facilitate species interpretation using the molecular characters described in this study, we designate S3.001 from Sorghum bicolor as an epitype; a culture of this specimen has been deposited in the ATCC and the CVS.

Comments. C. sublineolum also possesses several fixed autapomorphic characters that serve to uniquely distinguish the species from $C$. graminicola (positions are relative to the nucleotide sequence alignment of the epitype specimens): ITS1/5.8S/ ITS2 positions $25(\mathrm{~T}), 69-72$ (no bases), 100 (C), 101-102 (TC), 107 (no bases), 111 (A), 113-115 (GGG), 119-120 (CG), 138 (A), 414-416 (no bases), 514 (T), 522 (no base); MAT1-2 positions 105 (C), 116 (no base), 120 (G); and SOD2 positions 35 (no base), 37 (no base), 39 (A), 47 (T), 50 (no base), 52 (no base), 503 (no base), 508 (G), and 544-546 (GGA).

We have not listed a teleomorph state for the species; in a review of the species taxonomy, Sutton suggests that the teleomorph may be Glomerella cingulata var. sorghicola Saccas (62).

It is worth emphasizing that although $C$. graminicola is still frequently employed to describe Colletotrichum from sorghum, Sutton's 1980 emendment of the species description rendered such application of the name illegitimate. C. sublineolum is the validly established taxon describing Colletotrichum associated with sorghum; this distinction has been repeatedly confirmed through morphological examinations (10,12,25,59-61), host range and pathogenicity testing $(6,12,20,36,40)$, and molecular analyses $(12,19,25,31,45,52,55,56,67,68$, this study).

\section{DISCUSSION}

The purpose of this study was to explore the evolutionary history of the $C$. graminicola lineages that cause anthracnose disease in turfgrasses, in particular, we sought to identify the point at which interspecific boundaries have been erected between taxa, defining the extreme limits of gene flow and population-level processes.

Species boundaries. The phylogenetic analyses performed in this study generated an extremely well-supported hypothesis of evolutionary descent for the taxa currently recognized as C. graminicola sensu lato G.W. Wilson and conclusively established that there are two species within this circumscription. Although we employed several methods to identify reticulate evolution among the taxa, the evidence is overwhelmingly in favor of a long-standing biological isolation between these two distinct, monophyletic groups.

In light of the pattern of fixed nucleotide differences and the unique host plant associations observed between lineages of Colletotrichum from corn and from those isolates obtained from the $\mathrm{C} 3$ grasses in the subfamily Pooideae, the species level phylogenetic divergence present in $C$. graminicola sensu lato G.W. Wilson is unambiguous. We therefore propose to resurrect the species $C$. cereale to describe Colletotrichum from pooid grasses, and C. graminicola (Ces.) G.W. Wilson sensu stricto Sutton 1980 is reserved for the fungus pathogenic to corn, with each species uniquely characterized by their molecular identities at the ITSI/ 5.8S/ITS2, MAT1-2, and SOD2 loci and their host range. These physiological host range limitations are well documented in the literature $(2,6,12,20,36,38,40,41,43,44,72,73)$ and correspond with the emended phylogenetic species described in this paper. Since $C$. cereale likely has a much more extensive host range as a pathogen than that which is explicitly described in this manuscript, we emphasize that it is the pattern of fixed differences on the molecular level and the association with grasses of the Pooideae that serve uniquely to distinguish this species, rather than strict pathogenicity criteria. This is an important distinction: C. cereale transcends its ability to induce anthracnose disease symptoms in a given host plant, since the species is capable of inhabiting many pooid grasses without inducing disease in the host.

Even in our most conservative analyses, where only the most reliable, unconflicted nucleotide characters are considered, these species fully meet the criteria of the genealogical concordance phylogenetic species concept (64), which is capable of efficiently and objectively marking species boundaries in asexually reproducing organisms such as Colletotrichum that defy characterization based upon morphological or reproductive criteria. The specific designation of these groups is dictated by taxonomic priority: C. graminicola, as Dicladium graminicolum, was first described by Cesati (15) in 1852 from the stems of corn and barnyard grass (Echinochloa crus-galli); the first formal description of Colletotrichum from a pooid grass did not occur until 1909 (54) when Selby and Manns first described C. cereale. Most of the taxonomic uncertainty surrounding the circumscription of $C$. graminicola completely by-passed members of the genus found in association with pooid grasses and instead concentrated on those strains responsible for economically important levels of disease in the host plant: corn, sorghum, and sugarcane. Even Sutton, the recognized authority in Colletotrichum systematics, has evaluated only two pooid strains as $C$. graminicola (from Avena sativa) using conidial measurements. Herbaria material inspected from Bromus spp., Calamagrostis epigeoios, C. villosa, C. neglecta, Lolium perenne, and Poa annua were accepted by Sutton to be $C$. dematium since a distinction between these taxa could not be made based on morphological structures examined (58). The study of Selby and Manns that served to erect $C$. cereale was not cited or discussed in any of Sutton's publications (58-62).

Because our current research goals are focused on the population dynamics of Colletotrichum from pooid grass hosts rather than conducting an expansive taxonomic survey of the genus, we have not sampled Colletotrichum from the other $\mathrm{C} 4$ grasses evaluated by Wilson (Panicum spp., Echinochloa crus-galli), leaving the species status of these members of the genus Colletotrichum still undefined; Sutton's 1980 treatment of C. graminicola precludes the legitimate use of the name to describe these taxa. In a review of the taxonomy of the genus Colletotrichum in 1992 (62), Sutton introduced the idea that a still unnamed species closely related to C. falcatum occurs on grass hosts other than sugarcane, basing his suggestion upon earlier morphological studies of samples from several "miscellaneous" C4 grass genera of the Panicoideae including Andropogon, Digitaria, Echinochloa, Eleusine, Eragrostis, Miscanthus, Panicum, and Rottboellia (58). Molecular data presented in two recent phylogenetic analyses $(12,25)$ corroborate Sutton's hypothesis, providing additional evidence that a new species will need to be erected to describe properly the Colletotrichum associated with Echinochloa spp., since these taxa do not conform phylogenetically to any of the species now described from graminaceous host plants.

One particular question that remains unresolved is the relationship between $C$. graminicola and $C$. sublineolum: have they recently diverged from a common ancestor? This is an intriguing 
premise that continually arises in all of the evolutionary inferences, albeit with minimal support. For several years these two species, along with $C$. falcatum and $C$. caudatum, were considered to be varietal forms of a single species $(5,43,44)$, and the unique status of $C$. sublineolum is still rejected by many researchers of sorghum anthracnose (e.g., 69). Is this association between species real, or is it an artifact of ancestral polymorphisms? To fully consider this possibility, a substantially larger portion of the genome should be sampled, with an extended sampling from these taxa along with their sister species from other $\mathrm{C} 4$ grass hosts.

Unresolved, potentially species-level divergences. We envision that $C$. cereale sensu lato Crouch, Clarke, and Hillman may eventually need to be further subdivided-minimally into two species, and potentially into as many as four distinct species based solely upon this limited sampling. We regard the description of $C$. cereale to be a species group rather than a single homogeneous species, but the data from the present study are inadequate for the purpose of formally proposing subdivision of the group. Both ML and MP phylogenetic inferences and the splitsgraph strongly support the divergence of $C$. cereale clades A and $\mathrm{B}$, but the phylogeny of the data set reduced of all potentially incompatible sites does not recover these lineages as independent entities. While this discrepancy is likely due to the elimination of a great many of the informative characters from the analysis rather than continued gene flow, we cannot at this time confidently suggest the establishment of two unique species based upon these data alone, since the eliminated characters may have yielded erroneous species phylogenies. It is not surprising that a great deal of potentially misleading data can be found when considering a group of organisms so close to the population level, as any number of processes can result in inconsistent, misleading conclusions due to incomplete lineage sorting, recombination, and hybridization. We expect that the application of several analytical techniques-vegetative compatibility, host range analysis, pathogenicity, and virulence-will be required before these unique groups can be defined in a substantive, biologically meaningful manner. This work merely represents the first step in an ongoing process; nevertheless, it does provide a vital framework for future experimental work.

The evolutionary history of $\boldsymbol{C}$. cereale. In any phylogenetic analysis, the assumption that only a single phylogeny underlies the evolution of the population sampled is violated by the presence of recombination. Recombination is a truly creative force in organismal biology, but has the unfortunate side effect of completely confounding the accurate estimation of phylogenies when present $(14,48,49$ for reviews). This is particularly true in sexual species and, as our data will attest, in putatively asexual entities like those found in the genus Colletotrichum. It is evident that although $C$. cereale may for the most part propagate in an asexual fashion, recombination between taxa has occurred, as independently estimated by the split-decomposition network and compatibility matrix analysis; results from transposon RFLP fingerprinting assays also confirm the existence of mosaic genotypes in the species group (J. Crouch, B. B. Clarke, and B. I. Hillman, unpublished data). Although the three individual gene genealogies considered in this study were topologically congruent, suggesting a clonal, nonrecombining species history, overall our data provide evidence for the presence of recombination that is not reflected in the tree topologies. Many experts in the field of evolutionary biology recommend using a combination of assays to detect recombination in order to maximize the possibility of identifying recombination with a minimum of false positives (50 for review). In our research, three separate analyses detected the potential for recombination between $C$. cereale clades A and B; we believe these data are sufficient to recommend further analysis before establishing these clades as phylogenetic species when they may in fact only represent divergent populations.
Regardless of whether one accepts the clades of $C$. cereale as individual species or simply highly divergent populations, there are undeniably two unique lineages of this fungus causing disease in turfgrasses maintained as golf course greens. The clade A isolates are geographically widespread and were isolated from numerous turfgrass and noncultivated C3 pooid grass species; they are the numerically dominant form of $C$. cereale in the sample discussed in this manuscript and in our entire culture collection. To date, over 200 additional specimens of $C$. cereale in our culture collection have been identified as part of clade A through the application of a PCR-based screening protocol using lineage-specific transposable element primers, in some instances supported by sequence analysis. Also included in $C$. cereale clade A are several isolates from wheat plants from the Midwest United States, as inferred from SOD2 and ITS sequences (J. Crouch, B. B. Clarke, and B. I. Hillman, unpublished data). In contrast, the clade B lineage is quite rarely encountered and appears to have a much more restricted host range and geographic distribution. Additionally, there are several hints of an association between host plant derivation and the $C$. cereale clade B lineage: the phylogenetic tree topology in particular shows an almost perfect division between Agrostis stolonifera and Poa annua isolates within this lineage. Whether the peculiarities of clade B with respect to distribution and host range are based on real phenomena or have arisen due to sampling bias will require further study.

One of the most important conclusions generated by these analyses is the identification of the very common and widely distributed $\mathrm{H} 5$ ancestral haplotype in the $C$. cereale clade A population. The proposition that all North American $C$. cereale lineages are ultimately derived from the H5 haplotype, regardless of their host-plant derivation, could have very important implications for the development of effective disease control strategies.

\section{ACKNOWLEDGMENTS}

We are grateful to Lisa Vaillancourt for her suggestion to use the $C$. graminicola mating-type locus as a phylogenetic marker in our analysis and for sharing a pre-publication version of reference 25 while this manuscript was in review. We thank Richard Buckley and Sabrina Tirpak of the Rutgers Disease Diagnostic Clinic for identifying and supplying Colletotrichum-infected turfgrass specimens, and to several individuals who generously provided fungal cultures for use in this study: Jim Baird, Gary Bergstrom, Tom Hsiang, Noel Jackson, Randy Kane, Peter Oudemans, Wakar Uddin, Lisa Vaillancourt, and Frank Wong. Special thanks to the herbarium staff of the New York Botanical Garden for their assistance with herbarium specimens. We also thank Karen Garrett and Ned Tisserat for the use of laboratory facilities and assistance with sampling conducted at the Konza Prairie Biological Station (a preserve of The Nature Conservancy managed by the Division of Biology, Kansas State University), and Karl Kjer for assistance with the data sets, phylogenetic analyses, and for comments on the manuscript. We also thank Tom Harrington, Jim White, and three anonymous reviewers, who provided valuable discussions, comments, and criticisms that greatly improved the quality of this manuscript. J. A. Crouch was supported by a Rutgers Excellence Fellowship and a Land Institute Natural Systems Agriculture Fellowship. This project was funded by the Rutgers Center for Turfgrass Science.

\section{LITERATURE CITED}

1. Akaike, H. 1974. A new look at the statistical model identification. IEEE Trans. Automatic Control 19:716-723.

2. Ali, M. M. 1962. Factors influencing pathogenicity of three isolates of Colletotrichum graminicola on wheat. Mycopath. Mycol. Appl. XIX:161166.

3. Altschul, S. F., Gish, W., Miller, W., Myers, E. W., and Lipman, D. J. 1990. Basic local alignment search tool. J. Mol. Biol. 215:403-410.

4. Arie, T., Christiansen, S. K., Yoder, O. C., and Turgeon, B. G. 1997. Efficient cloning of ascomycete mating genes by PCR amplification of the conserved MAT HMG box. Fungal Genet. Biol. 21:118-130.

5. Arx, J. A. v. 1957. Die arten der gattung Colletotrichum Cda. Phytopathol. Z. 29:413-468. 
6. Backman, P. A., Landershoot, P. J., and Huff, D. R. 1999. Variation in pathogenicity, morphology, and RAPD marker profiles in Colletotrichum graminicola from turfgrasses. Crop Sci. 39:1129-1135.

7. Balardin, R. S., Smith, J. J., and Kelly, J. D. 1999. Ribosomal DNA polymorphism in Colletotrichum lindemuthianum. Mycol. Res. 103:841-848.

8. Bandelt, H. J., and Dress, A. W. 1992. Split decomposition: A new and useful approach to phylogenetic analyses of distance data. Mol. Phylogenet. Evol. 1:242-252.

9. Barker, F. K., and Lutzoni, F. M. 2002. The utility of the incongruence length difference test. Syst. Biol. 51:625-637.

10. Baxter, A. P., van der Westhuizen, G. C. A., and Eicker, A. 1983. Morphology and taxonomy of South African isolates of Colletotrichum. South African J. Bot. 2:259-270.

11. Brasier, C. M. 2001. Rapid evolution of introduced plant pathogens via interspecific hybridization. BioScience 51:123-133.

12. Browning, M., Rowley, L. V., Zeng, P., Chandlee, J. M., and Jackson, N. 1999. Morphological, pathogenic, and genetic comparisons of Colletotrichum graminicola isolates from Poaceae. Plant Dis. 83:286-292.

13. Cannon, P. F., Bridge, P. D., and Monte, E. 2000. Linking the past, present, and future of Colletotrichum systematics. Pages 1-20 in: Colletotrichum: Host Specificity, Pathology, and Host-Pathogen Interaction. D. Prusky, S. Freeman, and M. B. Dickman, eds. The American Phytopathological Society, St. Paul, MN.

14. Carbone, I., and Kohn, L. M. 2004. Inferring process from pattern in fungal population genetics. Pages 1-30 in: Fungal Genomics, Applied Mycology and Biotechnology Series. D. K. Arora and G. G. Khachatourians, eds. Elsevier Science, Burlington, MA.

15. Cesati, V. 1852. Klotzsch, herbarium vivum mycologicum, sistens fungorum per totam Germanium cresentium collection perfectam. Cent. XVII. Flora 35:398.

16. Chen, F., Goodwin, P. H., Khan, A., and Hsiang, T. 2002. Population structure and mating-type genes of Colletotrichum graminicola from Agrostis palustris. Can. J. Microbiol. 48:427-436.

17. Couch, B. C., Fudal, I., Lebrun, M.-H., Tharreau, D., Valent, B., Kim, P., Notteghem, J.-L., and Kohn, L. M. 2005. Origins of host-specific populations of the rice blast pathogen, Magnaporthe oryzae, in crop domestication with subsequent expansion of pandemic clones on rice and weeds of rice. Genetics 170:613-630.

18. Couch, H. B. 1979. Is it anthracnose or is it wilt? The Greensmaster 15:3-6.

19. Crouch, J., Clarke, B. B., and Hillman, B. I. 2005. Phylogenetic relationships and fungicide sensitivities of Colletotrichum graminicola isolates from turfgrass in North America. Int. Turfgrass Soc. Res. 10:186-195.

20. Dale, J. L. 1963. Corn anthracnose. Plant Dis. Rep. 47:245-249.

21. Darlu, P., and Lecointre, G. 2002. When does the incongruence length difference test fail? Mol. Biol. Evol. 19:432-437.

22. Dernoeden, P. H. 2000. Stresses and maladies of creeping bentgrass. Pages 44-48 in: Creeping Bentgrass Management: Summer Stresses, Weeds and Selected Maladies. Ann Arbor Press, Chelsea, MI.

23. Dolphin, K., Belshaw, R., Orme, C. D. L., and Quicke, D. L. J. 2000. Noise and incongruence: Interpreting results of the incongruence length difference test. Mol. Phylogenet. Evol. 17:401-406.

24. Dowton, M., and Austin, A. D. 2002. Increased congruence does not necessarily indicate increased phylogenetic accuracy-the behavior of the incongruence length difference test in mixed-model analysis. Syst. Biol. 51:19-31.

25. Du, M., Schardl, C. L., Nuckles, E. M., and Vaillancourt, L. 2005. Using mating-type gene sequences for improved phylogenetic resolution of Colletotrichum species complexes. Mycologia 97:641-658.

26. Fang, G. C., Hanau, R. M., and Vaillancourt, L. J. 2002. The SOD2 gene, encoding a manganese-type superoxide dismutase, is up-regulated during conidiogenesis in the plant-pathogenic fungus Colletotrichum graminicola. Fungal Genet. Biol. 36:155-165.

27. Felsenstein, J. 1985. Confidence limits on phylogenies: An approach using the bootstrap. Evolution 39:783-791.

28. Freeman, S. 2000. Genetic diversity and host specificity of Colletotrichum species on various fruits. Pages 131-144 in: Colletotrichum: Host Specificity, Pathology, and Host-Pathogen Interaction. D. Prusky, S. Freeman, and M. B. Dickman, eds. The American Phytopathological Society, St. Paul, MN

29. Hey, J., and Wakeley, J. 1997. A coalescent estimator of the population recombination rate. Genetics 145:833-846.

30. Horvath, B. J., and Vargas, J. M. 2004. Genetic variation among Colletotrichum graminicola isolates from four hosts using isozyme analysis. Plant Dis. 88:402-406.

31. Hsiang, T., and Goodwin, P. H. 2001. Ribosomal DNA sequence comparisons of Colletotrichum graminicola from turfgrasses and other hosts. Eur. J. Plant Pathol. 107:593-599.

32. Hudson, R. R., and Kaplan, N. L. 1985. Statistical properties of the number of recombination events in the history of a sample of DNA sequences. Genetics 111:147-164.
33. Huelsenbeck, J. P., and Rannala, B. 2004. Frequentist properties of Bayesian posterior probabilities of phylogenetic trees under simple and complex substitutional models. Syst. Biol. 53:904-913.

34. Huelsenbeck, J. P., and Ronquist, F. 2003. MrBayes 3: Bayesian phylogenetic inference under mixed models. Bioinformatics 19:1572-1574.

35. Huson, D. H. 1998. SplitsTree: Analyzing and visualizing evolutionary data. Bioinformatics 14:68-73

36. Jamil, F. F., and Nicholson, R. L. 1987. Susceptibility of corn to isolates of Colletotrichum graminicola pathogenic to other grasses. Plant Dis. 71:809-810.

37. Johnston, P. R., and Jones, D. 1997. Relationships among Colletotrichum isolates from fruit-rots assessed using rDNA sequences. Mycologia 89:420-430.

38. Kemp, G. H. J., Pretorius, Z. A., and Smith, J. 1991. Anthracnose of wheat in South Africa. Phytophylactia 23:177-179.

39. Larget, B., and Simon, D. L. 1999. Markov chain Monte Carlo algorithms for the Bayesian analysis of phylogenetic trees. Mol. Biol. Evol. 16:750759 .

40. LeBeau, F. J. 1950. Pathogenicity studies with Colletotrichum from different hosts on sorghum and sugarcane. Phytopathology 40:430-438.

41. LeBeau, F. J., Stokes, I. E., and Coleman, O. H. 1951. Anthracnose and red rot of sorghum. Vol. 1035. U.S. Dep. Agric., Washington, D.C.

42. Liyanage, H. D., McMillan, R. T., and Kistler, H. C. 1992. Two genetically distinct populations of Colletotrichum gloeosporioides from citrus. Phytopathology 82:1371-1376.

43. Messiaen, C. M., Lafon, R., and Malot, O. 1959. Necroses de racines, pourritures de tiges et verse parasitaire du Mais. Ann. Epiphyt. Ser. C. 10:441-474

44. Minussi, E., and Kimati, H. 1979. Taxonomy of Colletotrichum graminicola (Ces.) Wils. (sensu Arx, 1957). Rev. Centro Cienas Rurais 9:171187.

45. Moriwaki, J., Tsukiboshi, T., and Sato, T. 2002. Grouping of Colletotrichum species in Japan based on rDNA sequences. J. Gen. Plant Pathol. 68:307-320.

46. O’Donnell, K., and Cigelnik, E. 1997. Two divergent intragenomic rDNA ITS2 types within a monophyletic lineage of the fungus Fusarium are nonorthologous. Mol. Phylogenet. Evol. 7:103-116.

47. Posada, D., and Crandall, K. A. 1998. Modeltest: Testing the model of DNA substitution. Bioinformatics 14:817-818.

48. Posada, D., and Crandall, K. A. 2001. Intraspecific gene genealogies: Trees grafting into networks. Trends Ecol. Evol. 16:37-45.

49. Posada, D., and Crandall, K. A. 2002. The effect of recombination on the accuracy of phylogeny estimation. J. Mol. Evol. 54:396-402.

50. Posada, D., Crandall, K. A., and Holmes, E. C. 2002. Recombination in evolutionary genomics. Annu. Rev. Genet. 36:75-97.

51. Price, E. W., and Carbone, I. 2005. SNAP: Workbench management tool for evolutionary population genetic analysis. Bioinformatics 21:402-404.

52. Randhir, R. J., and Hanau, R. M. 1997. Size and complexity of the nuclear genome of Colletotrichum graminicola. Appl. Environ. Microbiol. 63:4001-4004.

53. Rozas, J., Sanchez-DelBarrio, J. C., Messeguel, X., and Rozas, R. 2003. DnaSP, DNA sequence polymorphism analyses by the coalescent and other methods. Bioinformatics 19:2496-2497.

54. Selby, A. D., and Manns, T. F. 1909. Studies in diseases of cereals and grasses. Ohio Agric. Exp. Stn. Bull. 203:207.

55. Sherriff, C., Whelan, M. J., Arnold, G. M., and Bailey, J. A. 1995. rDNA sequence analysis confirms the distinction between Colletotrichum graminicola and C. sublineolum. Mycol. Res. 99:475-478.

56. Sreenivasaprasad, S., Mills, P. R., Meehan, B. M., and Brown, A. E. 1996. Phylogeny and systematics of 18 Colletotrichum species based on ribosomal DNA spacer sequences. Genome 39:499-512.

57. Sullivan, J. 1996. Combining data with different distributions of amongsite rate variation. Syst. Biol. 45:375-380.

58. Sutton, B. C. 1965. Studies on the taxonomy of Colletotrichum Cda with especial reference to $C$. graminicola (Ces.) Wilson. University of London, London.

59. Sutton, B. C. 1966. Development of fruitifications in Colletotrichum graminicola (Ces.) Wils. and related species. Can. J. Bot. 44:887-897.

60. Sutton, B. C. 1968. The appressoria of Colletotrichum graminicola and $C$ falcatum. Can. J. Bot. 46:873-876

61. Sutton, B. C. 1980. The coelomycetes: Fungi imperfecti with pycnidia, acervuli, and stromata. Commonwealth Mycological Institute, Kew, UK.

62. Sutton, B. C. 1992. The genus Glomerella and its anamorph Colletotrichum. Pages 1-26 in: Colletotrichum: Biology, Pathology and Control. J. A. Bailey and M. J. Jeger, eds. CAB International, Wallingford, UK.

63. Swofford, D. L. 2000. PAUP*: Phylogenetic analysis using parsimony (*and other methods). Sinauer Associates, Sunderland, MA.

64. Taylor, J. W., Jacobson, D. J., Kroken, S., Kasuga, T., Geiser, D. M. Hibbett, D. S., and Fisher, M. C. 2000. Phylogenetic species recognition and species concepts in fungi. Fungal Genet. Biol. 31:21-32. 
65. Thompson, J. D., Higgins, D. G., and Gibson, T. J. 1994. CLUSTAL W: Improving the sensitivity of progressive multiple sequence alignment through sequence weighting, position-specific gap penalties, and matrix choice. Nucleic Acids Res. 22:4673-4680.

66. Vaillancourt, L., Du, M., Wang, J., Rollins, J., and Hanau, R. 2000. Genetic analysis of cross fertility between two self-sterile strains of Glomerella graminicola. Mycologia 92:430-435.

67. Vaillancourt, L. J., and Hanau, R. M. 1991. A method for genetic analysis of Glomerella graminicola (Colletotrichum graminicola) from maize. Phytopathology 81:530-534.

68. Vaillancourt, L. J., and Hanau, R. M. 1992. Genetic and morphological comparisons of Glomerella (Colletotrichum) isolates from maize and sorghum. Exp. Mycol. 16:219-229.

69. Valero, H. M., Resende, M. A., Weikert-Oliveira, R. C. B., and Casela, C. R.
2005. Virulence and molecular diversity in Colletotrichum graminicola from Brazil. Mycopathologia 159:449-459.

70. White, T. J., Bruns, T., Lee, S., and Taylor, J. 1990. Amplification and direct sequencing of fungal ribosomal RNA genes for phylogenetics. Pages 315-322 in: PCR Protocols: A Guide to Methods and Applications. M. A. Innis, D. H. Gelfand, J. J. Sninsky, and T. J. White, eds. Academic Press, San Diego.

71. Wilson, G. W. 1914. The identity of the anthracnose of grasses in the United States. Phytopathology 4:106-112.

72. Zeiders, K. E. 1987. Leaf spot of Indiangrass caused by Colletotrichum caudatum. Plant Dis. 71:348-350.

73. Zwillenberg, H. H. L. 1959. Colletotrichum graminicola (Ces.) Wilson auf mais und verschiedenen anderen Pflanzen. Phytopathol. Z. 34:417425 . 